PDRTIONS OF THIS REPORT ARE ILLEGIBLE. It has been reproduced from the best available copy to permit the broadest possible avail.

i ability.

\title{
DESIGN OF GA THERMOCHEMICAL WAiER-SPLITTING PROCESS FOR THE MIRROR ADVANCED REACTOR SYSTEM
}

\author{
by \\ L. C. BROWN
}

Work supported by

Lawrence Livermore National Laboratory

Subcontract No. 2189401

GA PROJECT 3360

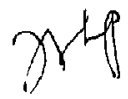
APRIL 1983 


\section{FOREHORD}

GA interfaced the sulfur-iodine thermochemical water-splitting cycle to the Mirror Advanced Reactor System (MARS). The results of this effort follow as one section and part of a second section to be included in the MARS final report. Section 5 describes the process and its interface to the reactor. Partial Section 7 gives the capital and operating costs for the hydrogen plant. 
SECTION 5.0

\section{INTERFACING THE GA CYCLE}

Contributor:

L. Brown

\section{TABLE OF CONTENTS}

Section

Page

5.0 interfacing the ga CYCLE . . . . . . . . . . . . 5-1

5.1 Base Chemical Process . . . . . . . . . . . . . . 5-1

5.2 Recent Developments in Process Chemistry . . . . . . . . 5-3

5.2.1 HI Decomposition Vfa Homogenous Catalysis . . . . . . . 5-4

5.2.2 Sulfur-sulfuric Acid Chenical Energy Storage System . . . . 5-5

5.3 Plant Uesign Status . . . . . . . . . . . . . 5-7

5.4 Main Solution Reaction Step (Section 1 ) . . . . . . . 5-7

5.4 .1 Design Considerations . . . . . . . . . . . 5-7

5.4 .2 Heat Exchanger Reaction . . . . . . . . . 5-10

5.4 .3 Lower Phase $\mathrm{SO}_{2}$ Stripper. . . . . . . . . . . . . . 5-11

5.4 .4 Boost Reactor . . . . . . . . . . . . . 5-11

5.4.5 Scrubbing Reactors. . . . . . . . . . . 5-12

5.4.5 Heat and Power Recovery . . . . . . . . . . 5-13

$5.5 \mathrm{H}_{2} \mathrm{SO}_{4}$ Processing Step (Section II) . . . . . . . . . 5-13

5.5.1 Design Considerations . . . . . . . . . . . 5-13

5.5 .2 Acid Concentration . . . . . . . . . . . 5-15

$5.5 .3 \mathrm{H}_{2} \mathrm{SO}_{4}$ Vaporizer . . . . . . . . . . . . . 5-17

$5.5 .4 \mathrm{SO}_{3}$ Deconposer $\ldots \ldots \ldots \ldots \ldots$. . . . . . . . . . . . . . .

5.5.5 Decomposer Recuperator . . . . . . . . . 5-18

5.5 .6 Decomposer Cooters $\ldots \ldots \ldots$. . . . . . . . . . .21 


\section{TABLE OF CONTENTS (Continued)}

\section{Section}

5.6 HI Concentration Step (Section III) . . . . . . . . 5-22

5.6.1 Design Considerations . . . . . . . . . . . 5-22

5.6 .2 Iodine Separation . . . . . . . . . . . . . 5-22

5.6.3 Hydrogen Iodide Distillation Column . . . . . . . . 5-24

5.6.4 Phospharic Acid Concentration . . . . . . . . . . . 5-25

5.7 HI Decomposition Step (Section IV) . . . . . . . . 5-26

5.7.1 Design Considerations . . . . . . . . . . . 5-26

5.7 .2 H] Decomposition. . . . . . . . . . . . . 5-26

5.7 .3 HI-I2 Distillation. . . . . . . . . . . . 5-28

5.7 .4 Hydrogen Cleanup. . . . . . . . . . . . . . . 5-29

5.8 Materials Selection for the Thermochemical Plant . . . . . . 5-30

5.8.1 Materials Selection for Section 1. . . . . . . . 5-30

5.8.2 Materials Selection for Section II. . . . . . . . . . 5-32

5.8.3 Materials Selection for Sections III and IV . . . . . 5-39

5.9 Safety Considerations . . . . . . . . . . . 5-39

5.10 Plant Layout and Plot Plan . . . . . . . . . . . 5-40

5.10 .1 P1ant Layout. . . . . . . . . . . . . . . . . 5-41

5.10 .2 plot plan . . . . . . . . . . . . . 5-41

References . . . . . . . . . . . . . . . 5-41 
SECTION 5.0

List of Figures

Figure

Page

5.0-1 Overall Proces Flow Diagram for the TMR/Synfuels Hydrogen

Production Plant, 1981 Version ............. 5-2

5.4-1 Schematic of Section I, Reaction of $\mathrm{SO}_{2}$ with lodine and

Water to give $\mathrm{H}_{2} \mathrm{SO}_{4}$ and $\mathrm{HI}_{X}$ as Immiscible Liquid Products. . . . 5-9

5.5-1 Schematic of Section II, Concentration and

Decomposition of Sulfuric Acid ............... 5-14

5.5-2 Design for the $\mathrm{H}_{2} \mathrm{SO}_{4}$ Azeotrope Vaportzer . . . . . . . . . 5-16

5.5-3 Design of the Catalytic Fluidized Bed $\mathrm{SO}_{3}$ Decomposer

for the Two-Zone BTanket .............. 5-19

5.5-4 Design for the $\mathrm{SO}_{3}$ Decomposer Recuperator . . . . . . . . . 5-21

5.6-1 Schematic Flow DIagram of Section III,

Separation of $\mathrm{HI}_{\mathrm{X}}$ into $\mathrm{HI}, \mathrm{I}_{2}$ and $\mathrm{H}_{2} \mathrm{O} \ldots \ldots$ 5-23

5.7-1 Schematic Flow Diagram of Section IV, the HI

Decomposition Step........................ 57

5.10-1 TMR-Synfueis Thermochemical Hydrogen Production

Plant Plot Plan, 1981 Version ............ 5-41

\section{List of Tables}

Table

Page

5.8-1 Material Candidates for Handling Process Fluids

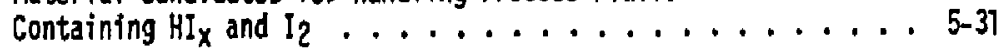

5.8-2 Candjate Construction Materials for Sulfuric Acid . . . . . 5-33

5.8-3 Sumtmary of Materials Selections for Heat Exchanger

and Vessel Materials for Section II of the ......... 5-38 


\subsection{INTERFACING THE GA CYCLE}

A viable fusion-powered thermochemical synfuels economy will only become reality through close matching of the thermal output of the fusion reactor to load deman's of the thermochemical process. Likewise, thermal energy sources within the chemical process must be matched to heat demands within the chemical process, and to heat requirements of the power production systems or power bottoming cycles.

We have proceeded from the integrated ThR driven synfuels plant developed two years ago (1) and shown in Figure 5.0-1 to develop an even deeper understanding of the factors governing the economic match of the fusion reactor to the synfuels plant. Last $(32)$ year major modifications were made to the sulfuric acid processing sections, and economies were realized through applying energy conservation techniques to the HI purification section. Further optomization of the sulfuric acid section has resulted in this improved design. Details of the preliminary design of each process unit in the chemical plant are discussed. The design description included consideration of heat and mass flow, equipinent sizes, and safety, and is based on chemical processes that have been demonstrated by laboratory experimentation.

\subsection{Base Chemical Process}

The GA water-splitting cycle $(2,3)$ may be described by the four equations:

$$
\begin{aligned}
& 2 \mathrm{H}_{2} \mathrm{O}+\mathrm{SO}_{2}+\mathrm{XI}-\mathrm{H}_{2} \mathrm{SO}_{4}+2 \mathrm{HI}_{x} \\
& \mathrm{H}_{2} \mathrm{SO}_{4} \rightarrow \mathrm{H}_{2} \mathrm{O}+\mathrm{SO}_{2}+1 / 2 \mathrm{O}_{2} \\
& 2 \mathrm{HI}_{x}-2 \mathrm{HI}+(\mathrm{X}-1) I_{2} \\
& 2 \mathrm{HI} \rightarrow \mathrm{H}_{2}+\mathrm{I}_{2}
\end{aligned}
$$




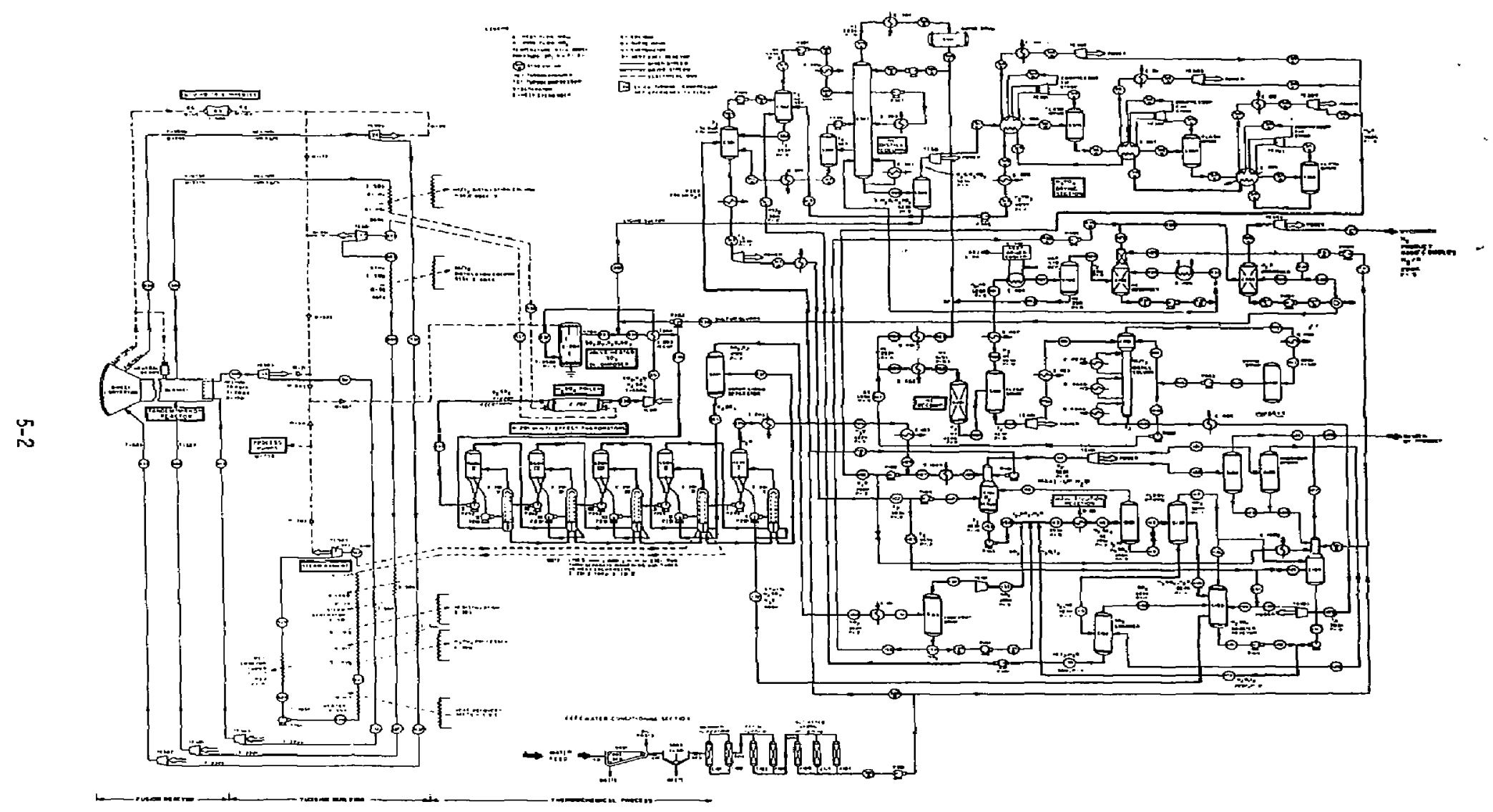

Figure 5.0-7 Overali Process Flow Diagram for the TMR/Synfuels Hydrogen Production Plant, 1981 Version 
These equations represent three chemical reactions and one separations process. In these equations the species $\mathrm{HI}_{\mathbf{X}}$ represents an aqueous complex of $\mathrm{HI}$ and $\mathrm{I}_{2}$ formed by reaction 1 . The $\mathrm{H}_{2} \mathrm{SO}_{4}$ product of reaction $\mathrm{I}$ is obtained as a moderately concentrated aqueous solution which is inmiscible with $\mathrm{HI}_{\mathrm{x}}$.

The overall process is divided into five sections for design purposes Sections I through IV roughly correspond to the four equations and section $Y$ represents the heat and energy transmission equipment required to match the fusion heat source to the chemicai process. Descriptions of sections I through IV occupy the rematnder of section 9 of this report. Section $V$ is described in report section 6 .

The developmental effori on the GA Sulfur-Iodine cycle has proceeded since 1974 along three parallel and mutually supportive lines:
- Chemical investigations
- Engineering f. owsheet development
- Process demonstration

Chemical investigations are the basis for the engineering flowsheet development and process demonstration. Synergistically, the flowsheet de:elopment and process demonstration efforts give impetus and direction to further chemical investigations. Likewise, each of these tasks raises new questions in its own area.

\subsection{Recent Developments in Process Chemistry}

The GA water-splitting process is not a static entity but is constantiy being upgraded. Information has recently been made available on two chemical innovations to the process $(2,4)$.

These techniques have been developed to the preliminary flowsheet stage under separate funding. HI decomposition via homogeneous catalysis (2) will eventually be incorporated into the fusion synfueis design, but since HI decomposition is relatively inexpensive there is little urgency. The Sulfur- 
Sulfuric Acid Chemical Energy Storage system (4), developed for solar applications, has the potential for long-term energy storage. Long-term storage could benefit a fusion synfuel plant by permitting the synfuel plant to maintain operation during scheduled and nonscheduied outing of the TRR. In addition, this system could provide on-sitis power for cold start-up of the TMR.

Neither of these process improvements have been included in this design. Discussion of this design resumes with section 5.3

\subsubsection{HI Decomposition Via Homogeneous Catalysis}

The present yersion of the sulfur-iodine water-spiftting process employs HI decomposition in the liquid phase. Theoretical calculations indicate that high conversion levels are possible using such a scheme, and indeed high conversions were verified experimentally $(10)$. In addition, the same article reparts that the magnitude of extrapolated rate data to high process temperatures appears sufficient to result in a viable process for $\mathrm{HI}$ decomposition. The above rate data were obtatned by extrapolating measured rate data from lower temperatures and pressures in batch studies performed on supported platinum and ruthenium catalysts.

Recentiy, some data for a supported platinum catalyst at closer to actual engineering temperatures and pressures were obtained in a new flowing liquid $\mathrm{Hl}$ bench-scale system. The rate value obtained gave credence to the use of the extrapolated lower temperature data and thus is verification of the present flowsheet and equipment sizing calculations.

Further in-depth studies, however, revealed a problem associated with the use of heterogeneolis catalysis to decompose liquid HI. This is associated with the finding that at least platinum, whether supported or not, does dissoive in the liquid $\mathrm{HI}$ to a non-negligible degree. This requires the use of some kind of catalyst recovery and remanufacture scheme. Catalyst recovery and remanufacture are commonplace in the chemical industry but add to the 
complexity and to the operational and capital costs of the overall process. It was due to the discovery of such an additional requirement of the process that some consideration was given to the use of homogeneous catalysis to decompose HI and to potential separation schemes inherent in the practical application of homogeneous catalysis.

A homogeneous catalyst concept has been devised (2) in which there is an innate separation of the catalyst from the HI liquid, thereby allowing the catalyst to be totally recycled to the reactor. The concept is based on some unique findings surrounding the pilase behavior of $\mathrm{HI}-\mathrm{I}_{2}-\mathrm{H}_{2} \mathrm{O}$ mixtures. For certain compositions of these three chemicals, two liquid phases in equilibrium can exist. One phase is a very dry phase of $H I$ and $I_{2}$; the other is an aqueous phase containing both $I_{2}$ and $H I$. It has been found that it is in this latter phase that certain homogeneous catalyst compounds tend to concentrate. This means that the aqueous phase acts essentially as the catalyst carrier and can be recycled to the HI decomposition reactor without having to recover the catalyst.

The potential advantages over a process empioying heterogeneous catalysts with the need to recover and remanufacture $100 \%$ of the catalyst are clear. The proposed homogeneous process has been conceptually flowsheeted (but at too late a date for inclusion in this overall process designl and major areas requiring investigation have been identified. The needed information consists mainiy in identifying the solubility and distribution of the catalyst in the fluids of the process train at engineering conditions, deternining the best area of the $\mathrm{HI}-\mathrm{I}_{2}-\mathrm{H}_{2} \mathrm{O}$ phase diagram in which to work, and determining the best schemes for catalyst recycle. The results of this work have supported this concept as a viable engineering process.

\subsubsection{The Sulfur-Sulfuric Acid Chemical Energy Storage System}

A sulfur-sulfuric acid energy storage system has been proposed for the $G A$ sulfur-iodine water-splitting cycle for use in conjunction with a solar heat source (4). This storage system has the potential for reducing the cost of fusion produced synfueis. During steady state operation of the TMR, a small 
amount of sulfuric acid could be coiverted to sulfur. During outages of the TMR, the sulfur could then be burned in air providing both the feed stock and energy required to operate the hydrogen piant. Potentially, the system could provide sufficient energy for the cold start of the TMR after an outage.

Conversion of sulfuric acid to sulfur is a two step process. The first step is al ready included in the water-splitting process, Equation 5.?. Formation of sulfur from sulfur dioxide is then accomplished by the disproportionation reaction.

$$
3 \mathrm{SO}_{2}+2 \mathrm{H}_{2} \mathrm{O} \rightarrow \mathrm{S}+2 \mathrm{H}_{2} \mathrm{SO}_{4}
$$

Kinecitcs of this reaction have been studied(11) at temperatures between 1000 and $1400^{\circ} \mathrm{C}$. The observed reaction rates are compatible with expected holding times for the $\mathrm{S}$ and dilute $\mathrm{H}_{2} \mathrm{SO}_{4}$ products.

Thermodynamicaliy, data from the JANAF Tables (12) and Giauque (13) suggest that the $\mathrm{H}_{2} \mathrm{SO}_{4}$ product can be made at up to $57 \% \mathrm{H}_{2} \mathrm{SO}_{4}$, which is the same concentration as the sulfur-iodine cycle sufluric acid product. This reaction, then, provices a method of upgrading an $\mathrm{SO}_{2}$ product into a much more valuable $S$ product at the expense of cyciling two-thirds of the $\mathrm{SO}_{2}$ back as $\mathrm{H}_{2} \mathrm{SO}_{4}$ solution. The stored energy in the $\mathrm{S}$ is recovered by combustion (in air) to $\mathrm{SO}_{2}$, and the produced $\mathrm{SO}_{2}$ is used in the $\mathrm{SO}_{2}-\mathrm{H}_{2} \mathrm{O}-\mathrm{I}_{2}$ reaction to make rejucle $\mathrm{H}_{2} \mathrm{SO}_{4}$ and $\mathrm{HI}$, which is the source of the $\mathrm{H}_{2}$ in the cycle.

The $\mathrm{SO}_{2}$ disproportionation makes a low-grade heat which is utilized in the cyc', (for instance, for dehydrating $\mathrm{H}_{2} \mathrm{SO}_{4}$ ), while the burning of the 5 makes the very high-grade heat which drives the hydrogen producing plant both electrically and thermally to produce $\mathrm{H}_{2} \mathrm{SO}_{4}$ and $\mathrm{H}_{2}$ from $\mathrm{SO}_{2}$. This storage cycle has inefficiencies as do all energy storage schemes; however, it provides high energy storage density in low cost, easily stored chemicals and easily supplies iarge quantities of high-grade heat. 


\subsection{Plant Design Statue}

The present plant design is based on the most recent integrated flowsheet. The flowsheets for the inain reaction (section I!, HI purificatiun (saction III), and HI decomposition (section IV) are the same as for previous reports $(1,32)$.

The sulfuric acid plocessiry section (section 1.: was revised to match the thermal energy avallable from the MaRS blanket. ile primary emphasis was upor. increasing thermal energy recovery of the sulfuric acid concentration step while maintaining a good thermai match to the blanket heat source. At this level of mreliminary design the size of the process equipment is deterained sufficient to development equipment costs. The design calculatioils make use of standard chemical engineering correlations for the sizing calculations. When the required physical and transport properties have been unavallable they hica been approximated.

\subsection{Main Soilution Rearioion Step (Section I)}

\subsubsection{Design Considerations}

The main solution reaction step, Section I of the :rocess, comprises all equipmene associated with the chemical reaction:

$$
2 \mathrm{H}_{2} \mathrm{O}\left(\mathrm{L}_{1}\right)+\mathrm{SO}_{2}(\mathrm{~g})+\mathrm{I}_{2}\left(\mathrm{~L}_{2}\right) \rightarrow \mathrm{H}_{2} \mathrm{SO}_{4}\left(\mathrm{~L}_{1}\right)+2 \mathrm{HI}\left(\mathrm{L}_{2}\right)
$$

where gaseous sulfur dioxide reacts with an excess of molten iodine and water to produce two fmoniscible liquid phases. The designation $L_{1}$ indicates that water is the major component in the $\mathrm{H}_{2} \mathrm{SO}_{4}$ product phase, and $\mathrm{L}_{2}$ that iodine is the major component in the HI product phase. The $\mathrm{H}_{2} \mathrm{SO}_{4}$ phase which is the lignter (lower density) phase, also contains a trace of iodine. T:e heavy phase, referred to as $\mathrm{HI}_{x}$, because it contains excess ictine in a complexed form, also contains water. The main solution reaction is exothermic and Section I requires no lisat input from the fusion reactor but exports a 
significant quantity of low-grade heat to a power bottoming cycle. The Section I process is shown schematically in Figure 5.4-1.

Even though Section I requires no beat input from the fusion reactor, the design of the main solution reaction step has a major influence on the overali process efficiency and thus upon the reactor size and the hydrogen production cost. Although decisions on heat and power recovery within section $I$ have an effect on efficiency, the composition and temperature of the light phase flowing to process Section II (the $\mathrm{H}_{2} \mathrm{SO}_{4}$ processing step) and of the heavy phase flowing to Section III (the HI concentration step) strongly influence the overail efficiency of the process. In the interest of efficiency, both streams should leave Section I at as high a temperature as possible and at the highest acid concentration posstble. Since the equilibrium of an exothermic reaction shifts towards the reactants as temperature is raised, a conpromise must be made between higl! temperature and high acid tirisentrations in the product. In deciding the operating conditions for Section I some economic trade-off calculations were made but a full-scale process optimization was not in the scope of this work. The basis for the resulting decisions, as well as those for the rest of this study, may best be termed "engineering judgnent." When trade-off calculations were not definitive, the decision was usually made on the side of "high efficiency" not "low capital cost."

Consideration of two factors dominates the design of Section I: (1) the large quantity of heat produced by the main solution reaction must be removed, and (2) the combination of hydrogen iodide and iodine in the heavy aqueous phase is extremely corrosive to materials normally employed for heat transfer surfaces. The oniy metals known to resist $\mathrm{HI}_{\mathrm{X}}$ are refractory metals such as niobium, tantalum, and molybdenum. The present design employs ntobium for heat transfer surfaces contacting $\mathrm{HI}_{X}$, which permits the reaction energy to be used in the power bottoming cycle.

Niabium is relatively expensive: therefore, to reduce the capital cost of Section 1, a number of design techniques have been employed which improve heat transfer and decrease tie amount of $\mathrm{Nb}$ required. Some of these are: 


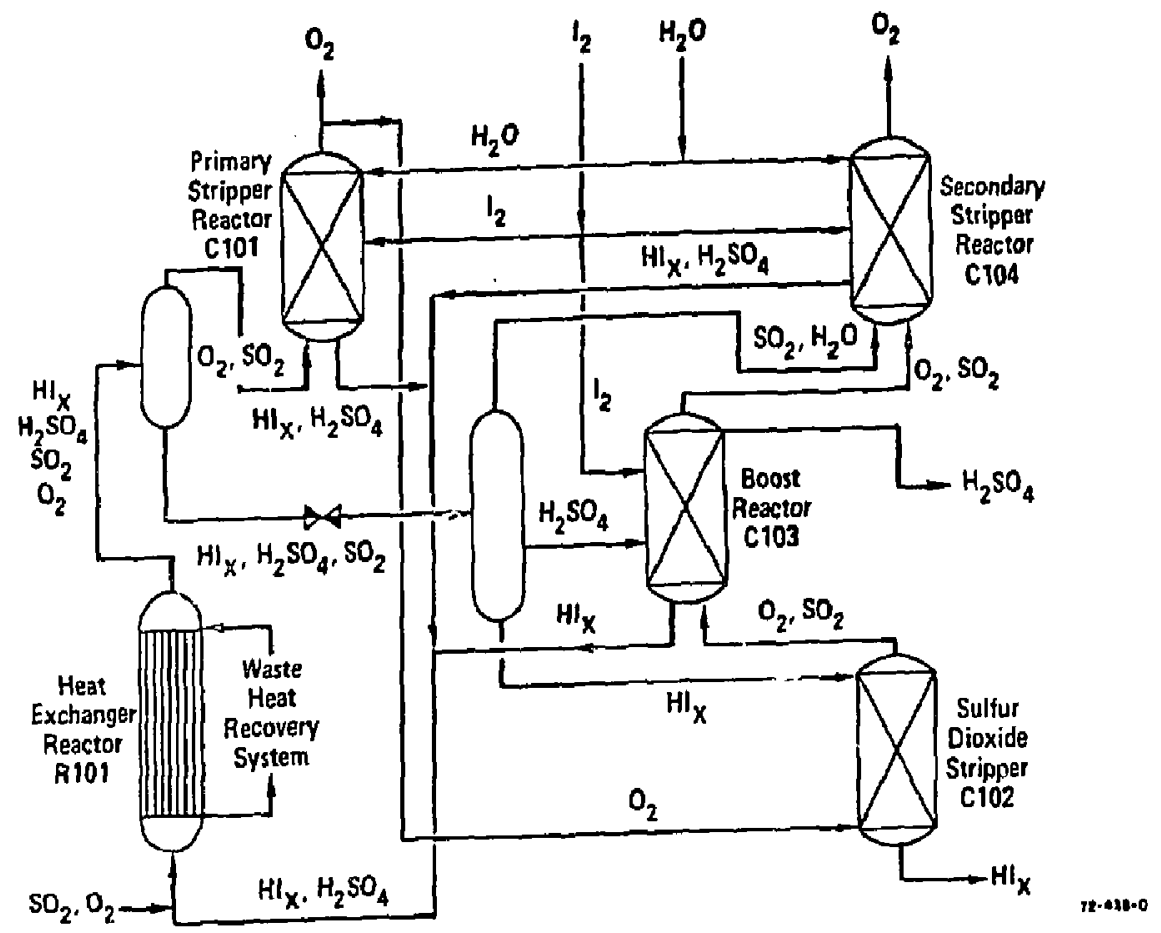

Figure 5.4-1 Schematic of Section 1, Reaction of $\mathrm{SO}_{2}$ with Iodine and water to give $\mathrm{H}_{2} \mathrm{SO}_{4}$ and $\mathrm{HI}_{x}$ as Immiscible Liquid Products 
1. Cool feed streams to Section 1. Prior to carrying out the main soiution reaction, we transfer the heat from the Section I feed streams to the power bottomfing cycle. This involves less expensive heat transfer materials than $\mathrm{Nb}$ and reduces the amount of heat transferred from the reaction products of the main solution reaction.

2. Operate adiabatically. Instead of cooling the reaction products from 393 to $368 \mathrm{~K}$ (to slift the equilibrium towards the products) and then reheating the separated products, we operate adfabatically, and maintain the desired production rate of the main solution resction by increasing the iodine concentration to provide the needed shift in the equilibrium.

3. Use direct-contact heat exchange. Where possible, we employ direct contact heat exchange between imissible liquid phases or gas and liquid phases.

4. Apply enhanced heat transfer techniques. Utilizing two-p'lase gas-liquid flow through the heat exchanger gives higher than nonmal convective heat transfer coefficients. Spłral-fluted tubing provides enhanced heat transfer and, due to the wall stiffening effect, permits thinner tube walls.

\subsubsection{Heat Exchanger Reactor}

Almost $52 \%$ of the chemical reaction forming $\mathrm{HI}$ and $\mathrm{H}_{2} \mathrm{SO}_{4}$ takes place in the Heat Exchanger Reactor (R-101 in the flow diagram of Figure 5.4-1) and in the piping immediately preceeding the reactor. The reactor selected is a shel1 and tube heat exchanger with fixed tube sheets. The vessel, tube sheets, and heads are fabricated from mild steel. The heads are lined with fluorocarbon and the spiral-fluted niobium tubes are weider to a niobium tube sheet liner. The process fluid is on the tube side of the heat exchanger and the shell side is part of the power bottoming cycle. 
Upstream of the heat exchanger, the $\mathrm{SO}_{2} / \mathrm{O}_{2}$ from Section II (sulfuric acid processing) is mixed with the predominantly lodine stream from the Boost Reactor (C-103) and aqueous s.treams from the scrubbing reactors ( $C-101$ and C-104). The combined streams react exothermically as they flow through a fluorocarbon-lined pipe and into the heat exchanging reactor. The pressure drop through the heat exchanger reduces the system pressure from an initial $0.50 \mathrm{MPa}$ to $0.44 \mathrm{MPa}$ at which point the temperature reaches $393 \mathrm{~K}$. At the exit of the heat exchanger the $\mathrm{O}_{2}$ is removed from the stream in the first of two separators (S-101). In the second separator (S-102), operating at $0.11 \mathrm{MPa}$, three phases separate: the heavy liquid phase $\left(H I_{X}\right)$, the light liquid phase $\left(\mathrm{H}_{2} \mathrm{O} / \mathrm{H}_{2} \mathrm{SO}_{4}\right)_{1}$, and a gas phase consisting of $\mathrm{SO}_{2}$ and steam. The vaporization of water and $\mathrm{SO}_{2}$ results in the temperature decreasing from $393 \mathrm{~K}$ to $385 \mathrm{~K}$.

\subsubsection{Lower Phase $\mathrm{SO}_{2}$ Stripper}

The lower phase solution $\left(\mathrm{HI}_{x}\right)$ is saturated with $\mathrm{SO}_{2}$ wrich when allowed to remain forms sulfur and $\mathrm{H}_{2} \mathrm{~S}$ via tramp reactions. An oxygen recycle stream strips most of th $\mathrm{SO}_{2}$ in a packed bed stripper (C-102) thus minimizing the tramp reactions. A minimum amount of oxygen is employed for this operation as the evaporation of water into the oxygen cools the $\mathrm{HI}_{x}$ requiring more heat input in Section III (HI purification). With a $10 \% \mathrm{O}_{2}$ recycle the $\mathrm{HI}_{X}$ is cooled from $385 \mathrm{~K}$ to $381 \mathrm{~K}$.

The stripper, sized for operation at $70 \%$ of flooding, is a standard packed coiumn design. The fluorocarbon-lined mild steel vessel is packed with $50 \mathrm{~mm}$ ceramic Raschig rings. Since the operating pressure is near atmospheric, a giass-lined steel vessel is a viable option but would require fluorocarbon packing to avoid liner damage.

\subsubsection{Boost Reactor}

In the boost reaction, the sulfuric acid concentration of the light phase is increased from $50 \%$ to $57 \%$ by contacting with molten iodine in the presence of sulfur dioxide. The increased $\mathrm{H}_{2} \mathrm{SO}_{4}$ concentration is realized through the action of the main solution reaction. Water is used up by reaction with $\mathrm{SO}_{2}$ 
and $\mathrm{I}_{2}$ to form $\mathrm{H}_{2} \mathrm{SO}_{4}$ and $\mathrm{HI}$. Over $7 \%$ of the total chemical reaction of Section I occurs in the Boost Reactor. Since the contact is performed in a countercurrent manner, the reactor also acts as a direct contact heat exchanger, rafsing the temperature of the suifuric acid stream from $383 \mathrm{~K}$ to $393 \mathrm{~K}$.

Al though the mechanical design of the Boost Reactor is straightforward, i.e., a fluorocarbon-1ined mild steel vessel packed with 50 mm ceramic Raschig rings, the sizing calcuiations are not. Common packed coilumns operate with either a gas rising through a decending liquid phase, or a light liquid phase rising through a decending neavy liquid phase. The Boost Reactor has both a gas phase $\left(\mathrm{SO}_{2}\right.$ in $\left.\mathrm{O}_{2}\right)$ and a light 7 iquid phase $\left(\mathrm{H}_{2} \mathrm{SO}_{4}\right.$ and water) rising through the docending heavy liquid phase $\left(I_{2}\right)$. The present design is based on adding the cross-sectional areas required if the gas and light liquid separately contacted the heavy liquid. This is a very conservative approach. We believe that a design based upon information gained in a pilot plant would result in a smaller Boost heactor vessel.

\subsubsection{Scruboing Reactors}

The oxygen is purified before discharge to the atmosphere in the Scrubbing, Reactors. The packed column reactors operate in a titration mode in which sufficient iodine is added to the scrub water in the lower part of the column to react stoichiometrically with the sulfur dioxide present in the oxygen. In the upper part of the column the oxygen is washed with pure water. The primary Scrubbing Reactor (C-101) operates at 0.44 Mpa purifying the gascous pi'oduct of the Heat Exchanger Reactor (R-101). Over 19\% of the Section I reartion takes place in the primary Scrubbing Reactor. Almost 22\% of the total reaction takes place in the secondary Scrubbing Recictor at $0.10 \mathrm{MPa}$. The secondary scrubber cleans up the oxygen stream exiting the Boost Reactor as well as the steam/ $\mathrm{SO}_{2}$ stream produced during depressurization of the liquid reaction product of the Heat Exchanger Reactor.

Both scrubbing reacturs perform a second function as direct contact heat exchangers. Oxygen leaving the process is cooled to near ambient conditions while preheating the water entering the process. The scrubber vesseis are of 
fluorocarbon-lifned mild steel and the packing is $50 \mathrm{~mm}$ ceramic Raschig rings. pllot plant tests may demonstrate reduced vessel costs. The upper portions of the scrubber contain only water and oxygen so no lining should be required in this area. Depending upon the temperatures reached in the lower portions of the scrubber, less expensive linings may be possible.

\subsubsection{Heat and Power Recovery}

The heat transferred to the power bottoming cycle from Section I totals $802 M_{t}$. The majority of this is transferred via the Heat Exchanger Reactor but significant quantities of heat are also transferred from the hot water products of Sections II and III and from the $\mathrm{SO}_{2} / \mathrm{O}_{2}$ product of Section II. Since the heat transfer materials used for water and $\mathrm{SC}_{2}$ are much less expensive than the niobium used in the Heat Exchanger Reactor, there is the potentfal for further cost reduction by performing more of the cooling on water and $\mathrm{SO}_{2}$ streams. U1timateiy an economic optimization must determine the split in heat transfer duties on the basis of minimum hydrogen production cost.

A total of $5.5 \mathrm{MN}$ is recovered in Section I using turbines for pressure reduction. Preliminary indications are that the turbines are economic but a final determination must await an analysis based on the hydrogen production cost resulting from this study.

\section{$5.5 \mathrm{H}_{2} \mathrm{SO}_{4}$ Processing Step (Section II)}

\subsubsection{Design Considerations}

The sulfuric acid processing step, Section II of the process, takes $57 \%$ $\mathrm{H}_{2} \mathrm{SO}_{4}$ from Section $\mathrm{I}$, decomposes the $\mathrm{H}_{2} \mathrm{SO}_{4}$ and returns the resulting $\mathrm{SO}_{2}, \mathrm{O}_{2}$, and $\mathrm{H}_{2} \mathrm{O}$ back to section 1. The process flow diagrams is given in Figure 5.5-1.

Major unit operations of Section II are sulfuric acid concentration, vaporization, and decomposition. Equipment layout and designs are based on previous work, but the section has been completely reflowsheeted to match the MARS blanket. Newly available thermodynamic data was used in the flowsheeting. 


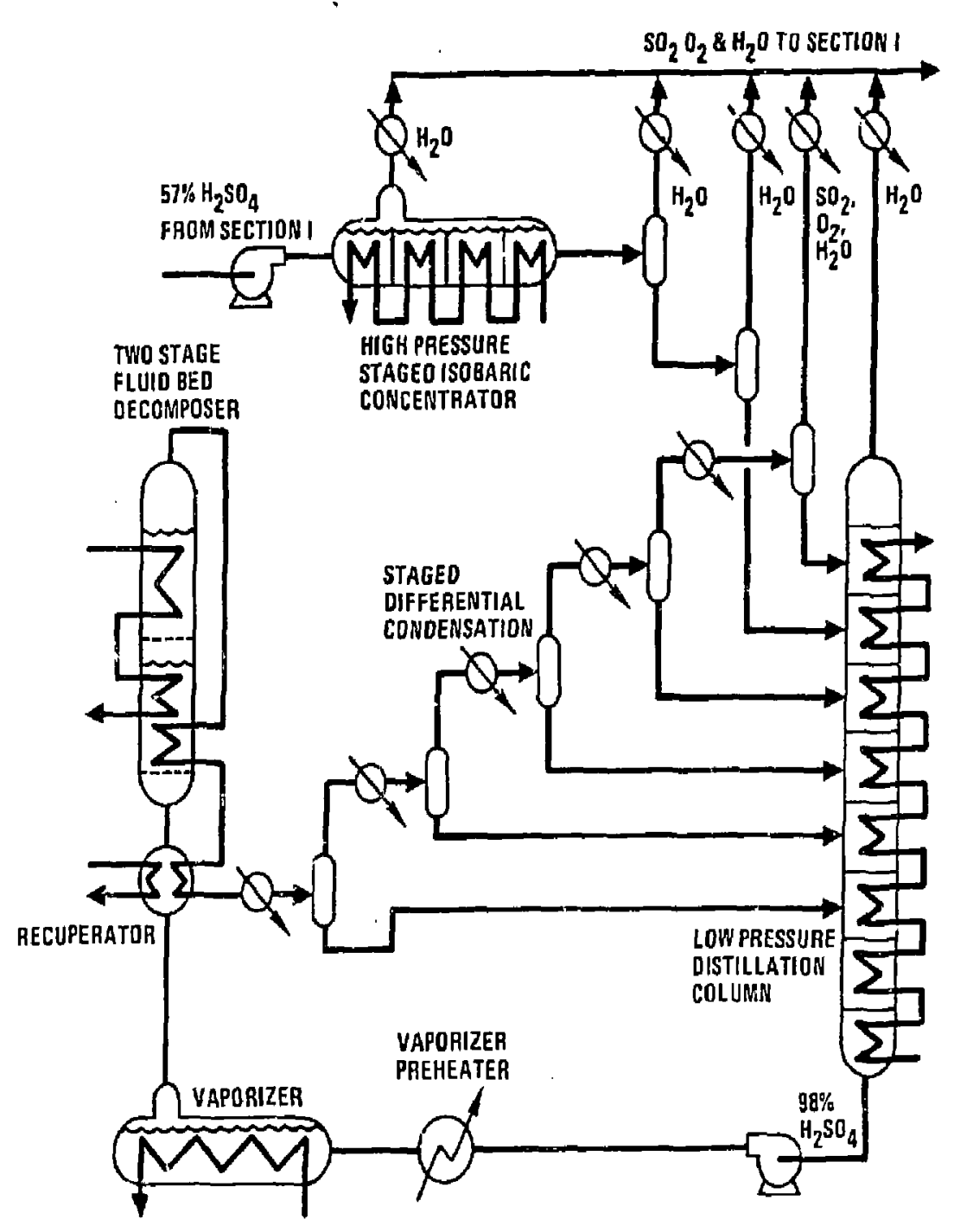

Figure 5.5-1 Schematic of Section II, Concentration and Decomposition of S:I furic Acid 


\subsubsection{Acid Concentration}

Early version: of the sulfur-iodine water-splitting process relled on vapor recompression to achieve high thermodynamic efficiency, though at high capital cost.

Several techniques were tried to accomplish the goal of heat recovery without vapor recompression. These inciuded multi-effect evaporators, pressure staged flash evaporators (adiabatic and non-adfabatic) and column evaporators. It became evident that no single technique could achieve the desired goal. A combination of four different concentration techniques was used in the final flowsheet.

Staged isobaric boiling at $7.5 \mathrm{MPa}$ is used to achieve the goal of water remove at useful steam temperatures. Low pressure distillation is used for final concentration of the acic to the azeotropic composition. Two adiabatic flash stages at $2.0 \mathrm{MPa}$ and $0.5 \mathrm{MPa}$ are used to match the isobaric staged boiling to the low pressure distillation column. Finally, staged partial condensation is used to remove $\mathrm{H}_{2} \mathrm{SO}_{4}$ from the decomposer product along with a minimum of water.

The isobaric staged boiling is accomplished in what can be best described as a horizontal distillation column. The design is patterned after the $\mathrm{H}_{2} \mathrm{SO}_{4}$ vaporizer described in previous work and shown in Figure 5.5-2. The horizontal yessel is fluorocarbon lined to protest the mild stee? from the sulfuric acid and brick lined to protect the fluorocarbon lining from heat. Siliconized silicon carbon tubes provide the heat of vaporization for the water. The vessel is partitioned into multiple stages by weirs made from acid brick. Above the weirs the vepor space is interconnected, with the vapor outlet at the low acid concentration end of the unit. Mixing of the vapors fram many stages results in a vapor composition typical of the mass average temperature. The vapors are cooled slightiy to condense the trace of acid present. The separated acid is added to the acid product of the cencentrator. After removal 


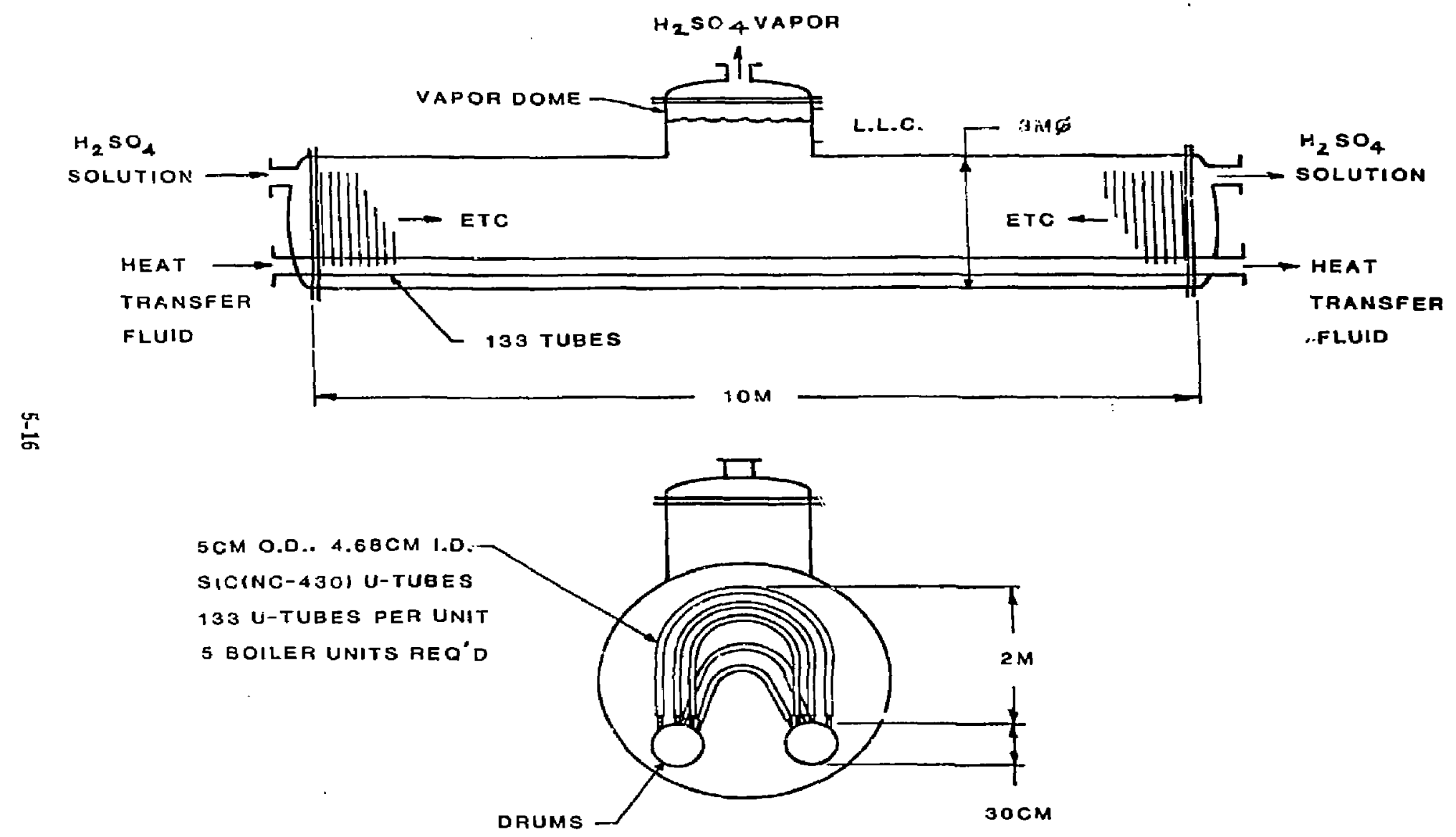

Figure 5.5-2 Design for the $\mathrm{H}_{2} \mathrm{SO}_{4}$ Azeotrope Vaporizer 
of the acid, the steam passes through a total condenser transferring the heat of condensation to the evaporators of section III.

The actd, concentrated to $79 \%$, at $7.5 \mathrm{MPa}$ is flashed first to $2.0 \mathrm{MPa}$ and then to $0.5 \mathrm{MPa}$ and again to $0.02 \mathrm{MPa}$. The vapors from the first two flashes are treated by partial condensation to remove $\mathrm{H}_{2} \mathrm{SO}_{4}$ and recycled to Section 1 . The combined liquid/vapor stream from the third flash is fed to the low pressure distillation column.

An eight-stage distillation column completes the concentration of the acid up to 98\%. Since the column must accormodate a large variation in liguid rates over its length, a tray type column is preferred over a packed column. Ceramic internals are used in the form of trough type trays. The bottom rebciler and the intermediate rebollers are again corstructed with sliticonized silicon carbide U-tubes. Each tray, except for the top, has its own intermediate reboiler.

The product gases from the decomposer are subjected to five stages of partial condensation so as to remove the undecomposed acid with a minimum of water. The liquid products from the partial condensation stages are returned to the atmospheric distillation column, the liquid from the final stage providing column refiux.

\subsection{3 $\mathrm{H}_{2} \mathrm{SO}_{4}$ Vaporizer}

The $\mathrm{H}_{2} \mathrm{SO}_{4}$ Vaporizer is a particulariy ciallenging design problem since either cerimic materials or high-sllicon metallic alloys neer to be employed to simultaneously withstand the $\mathrm{H}_{2} \mathrm{SO}_{4}$ corrosion and the $3.0 \mathrm{MPa}$ pressure from the helium heat transfer fluid.

Our best choice is to use siliconized silicon carbide U-tubes for the heat exchangers in the $\mathrm{H}_{2} \mathrm{SO}_{4}$ Boiler. This approach has been used on a developmental basis by the Norton Company (15) in conjunction with AiResedrch, Inc. for high pressure ( $5 \mathrm{MPa}$ ) helium "heat exchanger applications." He developed a special 
geometric configuration that established a rough optimization between the heat transfer and pumping losses in the helium and the boiling instabilities that could oceur in the liquid $\mathrm{H}_{2} \mathrm{SO}_{4}$. This configuration was show in Figure 5.5-2.

\subsection{4 $\mathrm{SO}_{3}$ Decomposer}

The decomposer consists of staged catalytic fluid bed reactors operating up to $1100 \mathrm{~K}$. Each unit contains internal heat exchanger tubes to provide the heat required to drive the highly endothermic $\mathrm{SO}_{3}$ decomposition reaction. Final conversion of $53 \%$ is achieved using both $\mathrm{Pt}$ on $\mathrm{2r}_{2} \mathrm{O}_{3}$ and $\mathrm{Fe}_{2} \mathrm{O}_{3}$ catalysts. The less expensive $\mathrm{Fe}_{2} \mathrm{O}_{3}$ catalyst is employed at $1100 \mathrm{k}$, but it loses its catalytic activity at significantly lower temperatures due to reversible sulfation. (5) Noble metal catalysts on non-sulfating supports may be used over the whole temperature range. Details of a single stage of the Fluid Bed Decomposition are given elsewhere ${ }^{(19)}$ so only a brief overview is provided here.

Figure 5.5-3 shows some of the details of the fluidized bed design, using $0.5 \mathrm{~mm}$ diameter aatalyst spheres. The fluldized bed is on the shell side of the unit with the helium on the rube side. The Ts across the helium film within the tube are about $20 \mathrm{~K}$, and the $T s$ on the outside of the tubes in the fluidized bed regton are expected to be around $14 \mathrm{~K}$. The helium $\mathrm{T}$ presents a difficult design problem and the $20 \mathrm{~K}$ is a compromise between higher helium source temperatures and helium pressure.

The Fluidized Bed Decomposer consists of eight two-stage decomposers in parallel to handle needed production rate. A portion of the heat for the low temperature bed of each bed is supplied while cooling the high temperature product gases. A separate tube bundle is used for recuperation.

\subsubsection{Decomposer Reouperator}

The Decomposer Recuperator is a heat exchanger unit that simultaneously preheats the feed to the decomposer using heat from the hot $\mathrm{SO}_{2}, \mathrm{O}_{2}, \mathrm{H}_{2} \mathrm{O}$, and $\mathrm{SO}_{3}$ that leave the decomposer. This unit is importani, since without it, a larger quantity of sensible heat in the temperature range of $680 \mathrm{~K}$ to $1000 \mathrm{~K}$ 


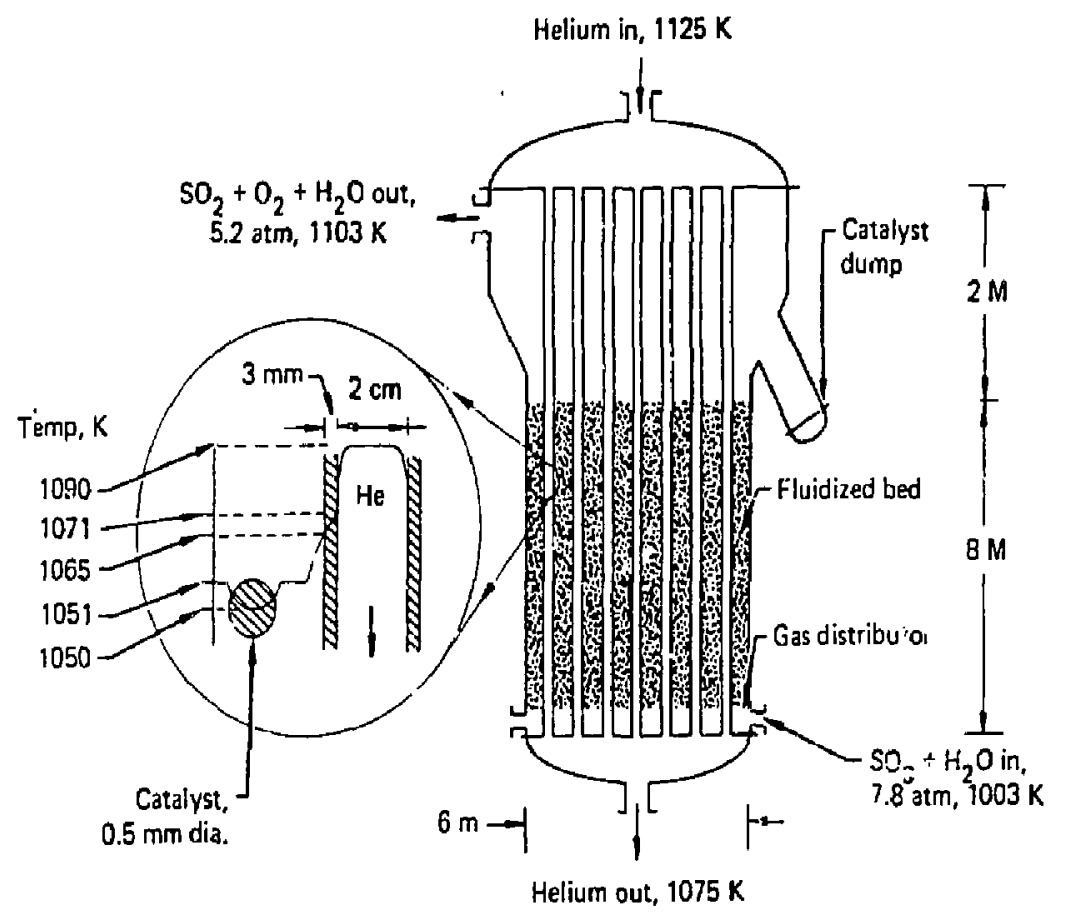

Figure 5.5-3 Design of the Catalytic Fluidized $\mathrm{Bed}_{3} \mathrm{SO}_{3}$ Decomposer for the Two-Zone Blanket 
would have to be suppifed from the blanket. In addition to the sensfble heat requirement, there is, of course, additional heat required to supply the endothermic heat for decomposing $\mathrm{SO}_{3}$ into $\mathrm{SO}_{2}$ and $\mathrm{O}_{2}$. Recuperation is insufficient to provide the total sensible heat required to treat the sulfuric acid vapors from the bolling point to the decomposer inlet temperature because the heat of decomposition of $\mathrm{H}_{2} \mathrm{SO}_{4}$ to $\mathrm{H}_{2} \mathrm{O}$ and $\mathrm{SO}_{3}$ must be provided over this temperature range. The Recuperator thus includes a "boost" loop of TMR-supolied heat. This Decompeser Recuperator is a difficult design to accomplish since it is a gas-to-gas heat exchanger, and these types of units characteristically have very low heat transfer coefficients. The result is a kigh pressure drop, high pumping power, large and expensive heat transfer areas, and high alloy cemperatures. The design we evolved was again a techno-economic compromise. he used incoloy-800H in a standard shell and tube configuration as shown in Figure 5.5-4.

\subsubsection{Decomposer CooTers}

The Decomposer Cooler continues cooling the decomposer product after recuperation is no inger possible. Heat removed in the decomposer coolers is supplied to the low pressure still and the multistage isobaric flash preheater. Sulfuric acid condenses out as the decomposer products are cooled. This sulfuric acid is removed in several stages. The liquid phase from the final cooler is predominantly water; therefore, it is relumed to serting I along with the gases.

5jlicon carbide is required where sulfuric acid is condensing. At high temperatures, before the onset of condensation. Incoloy $800 \mathrm{H}$ would suffice except that silicon carbidn is required for boiling sulfuric acid duty on the cold side of the tubes. After the majority of the sulfuric acid has been condensed and decanted, more conventional materials of construction are permitted. In the low temperature region the requirements of heating $57 \%$ sulfuric acid dominates the material selection. 


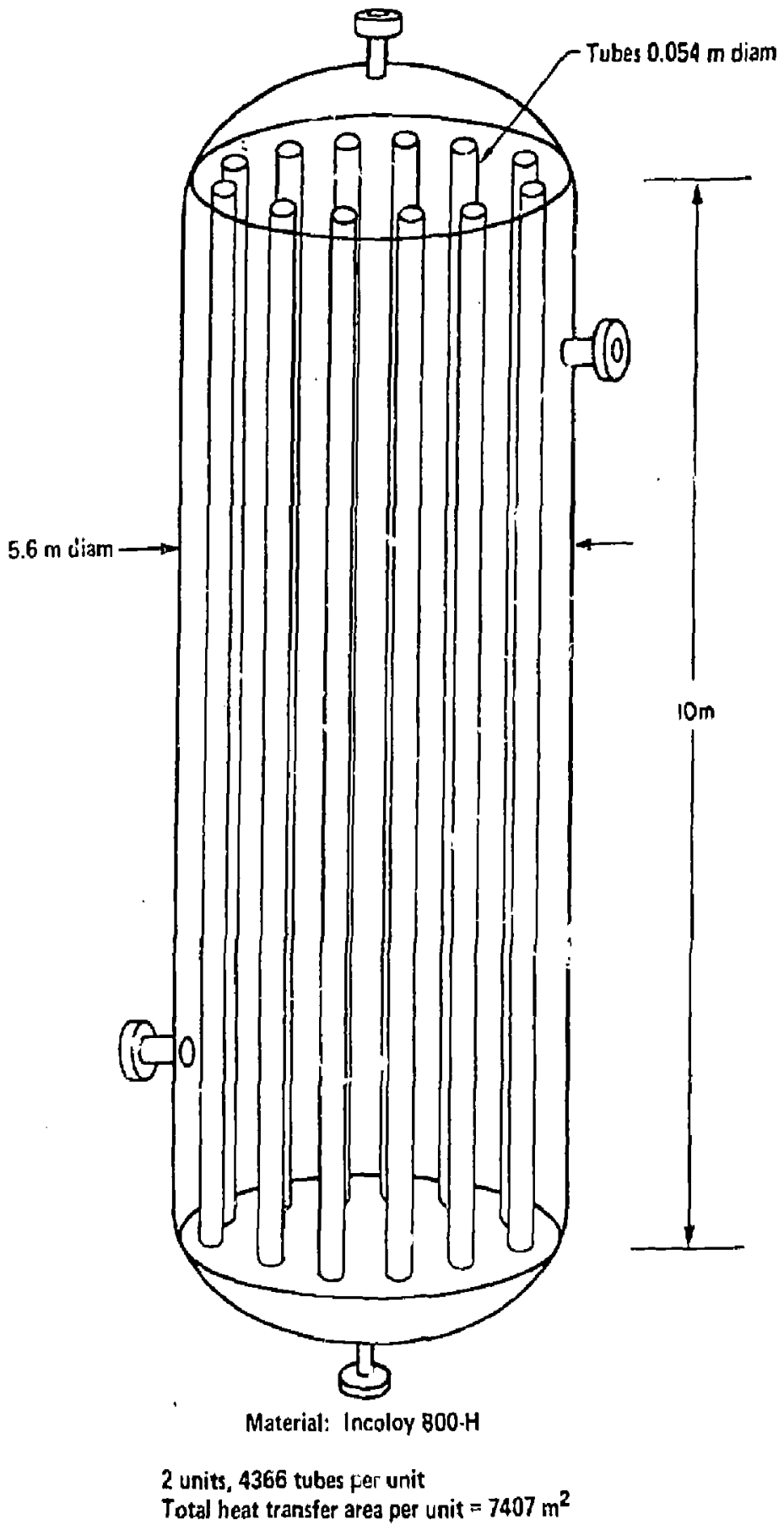

Figure 5.5-4 Design for the $\mathrm{SO}_{3}$ Decomposer Recuperator 


\subsection{HI Concentration Step (Section III)}

\subsubsection{Design Considerations}

The hydrogen fodide concentration step, Section III of the process, entails separation of a mixture of hydrogen iodide, iodine, and water $\left(\mathrm{HI}_{\mathrm{X}}\right)$ into its component parts. A simplified flow diagram of Section IIl is presented in Figure 5.6-1. The lodine and water are separately returned to Section I, the main solution reaction step, and the hydrogen lodide is decomposed in Section Iy of the process. The use of phosphoric acid as an extractive distillation agent, first proposed in $1975(20)$, remains as the referenc: process for sI purification. The al ternative of 11 quid $\mathrm{HBr}$ extraction, although attractive from a theoretical standpoint, is not yet able to compete with the $\mathrm{H}_{3} \mathrm{PO}_{4}$ process on an efficiency basis.

The system $\mathrm{HI}_{1} \mathrm{H}_{2} \mathrm{O}$ forms a maximum bolling azeotrope at a composition of 57\% HI which is approximately the composition of $\mathrm{HI}_{x}$ on an iadine free basis. Iodine is held in the $\mathrm{HI}_{-} \mathrm{H}_{2} \mathrm{O}$ solution through the formation of polyiodides such as $\mathrm{HI}_{3}, \mathrm{HI}_{5}, \mathrm{HI}_{7}$, etc., which are formed only in the presence of water. Addition of $\mathrm{H}_{3} \mathrm{PO}_{4}$ lowers the activity of water which performs two functions; first, it destabilizes the polyiodide complexes permitting jodine to form a separate liquid phase; secondly, it breaks the azeotrope which allows the HI to be distilled from the mixture. The HI distillation is performed under pressure so that liquid HI is avatlable for decomposition in Section IV. Water is removed from the phosphoric acid by evaporation, and the phosphoric acid is recycled back into the process.

\subsubsection{Iodine Separation}

Liquid iodine is separated from the $\mathrm{HI}_{X}$ in two steps. Both operational steps are performed in fluonncarbon-lined mild steel vessels packed with 20-mm ceramic saddles. In the iodine knock-out column (C-302), the $\mathrm{HI}_{x}$ is contacted counter-currently with $96 \% \mathrm{H}_{3} \mathrm{PO}_{4}$. The $\mathrm{HI}$ and $\mathrm{H}_{2} \mathrm{O}$ are extracted into the $\mathrm{H}_{3} \mathrm{PO}_{4}$, 


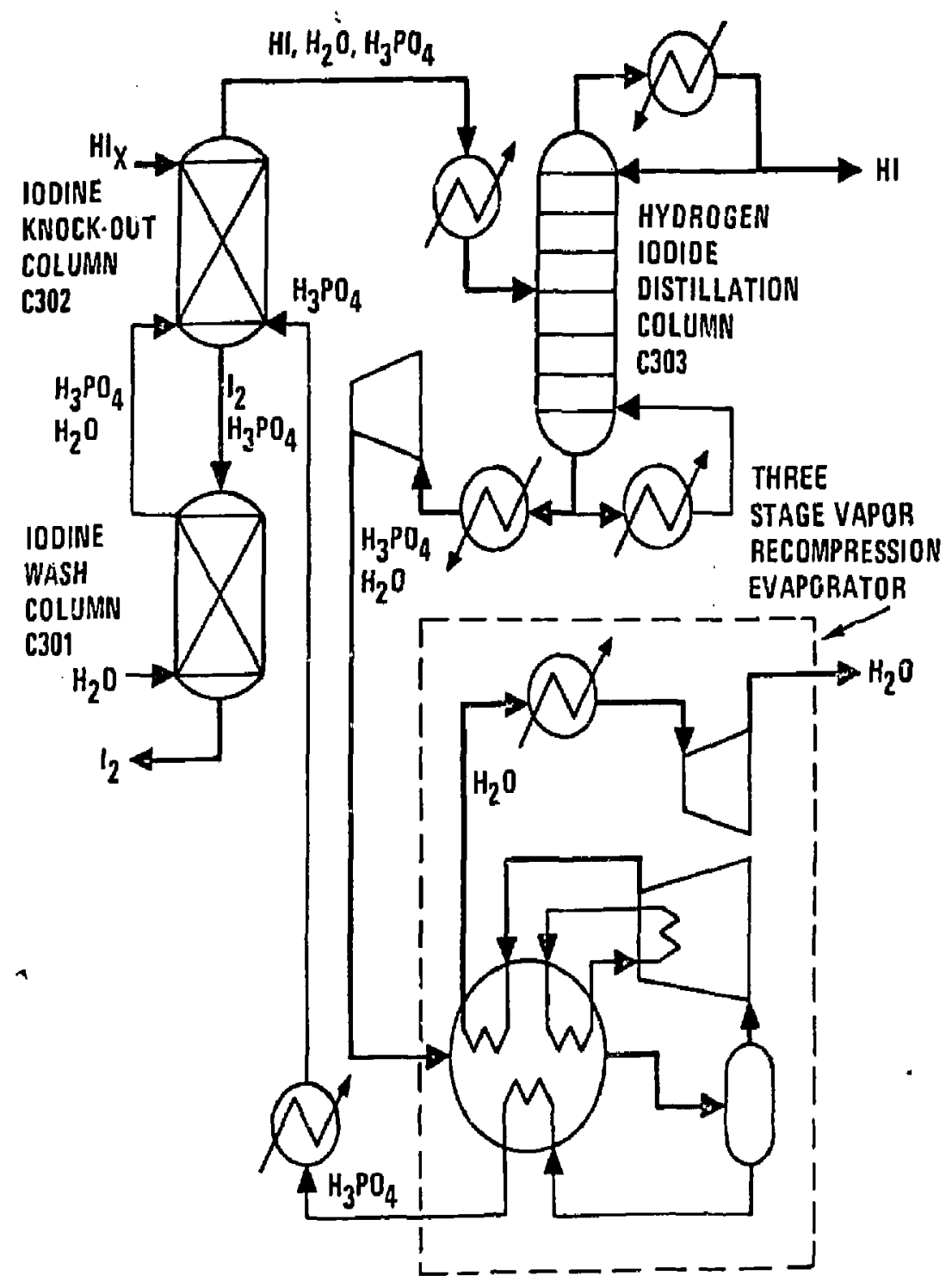

Figure 5.6-1 Schematic Flaw Diagram of Section III, Separation of Aqueous $\mathrm{HI}_{x}$ into $\mathrm{HI}, \mathrm{I}_{2}$, and $\mathrm{H}_{2} \mathrm{O}$ 
lesving wolten lodine saturated with $\mathrm{H}_{3} \mathrm{PO}_{4} \cdot \mathrm{H}_{3} \mathrm{PO}_{4}$ is washed away from the lodine with water in the lodine wash column (C-301). The wash column is operated at $0.3 \mathrm{MPa}$ and $393 \mathrm{~K}$ so as to maintain both lodine and water in the liquid state.

\subsubsection{Hydrogen Iodide Dist1llation Column}

$\mathrm{HI}$ is distilled from the $\mathrm{H}_{3} \mathrm{PO}_{4}$ solution in a plate colum operating at 0.9 MPa. Operation at this pressure requires a higher temperature in the bottoms than would be required at low pressure, but an expensive HI liquefaction step is eliminated. Efilcient use of the thermal energy, required for operation of the UI Ostillation Colum, is rade possible by producing the HI product as a liquid and thus eliminating the thermodynamic Inefficiency associated with a liquefaction compressor and that associated with production of power to operate it. Additic..-lly, an intermediate condenser allows part of the condensing heat to be withdrawn from the column at a useful temperature. Although a majority of the heat required to preheat the feed and to operate the column is obtalned by heat recovery within Section III, 355 MW is required from Section II at 523 $k$.

Design of the HI Distillation Column entailed a trade-off between capital and operating costs, Use of an intermediate condenser and operation at a relatively low reflux ratio reduce thermal energy requirements, but require more trays in the column for adequate chemical separation. The final design included 50 Hastelloy-C trays in a Hastelloy-C clad mild steel tower. The trays selected were the trough type, being a reasonable compromise between the higher effjciency, higher cost of bubble cap trays and the lower efficiency, lower cost of siew, trays.

An additional small design complication arises because the feed to the Distillation Column is saturated with iodine. Liquid iodine must be removed continuously from the middle of the column to avoid buildup. A stream, containing two liquid phases consisting of phosphoric acld and liquid iodine, is withdrawn from the iodine buildup regton. The phosphoric acid returns to the colum from the top of a liquisi-liquid separator and the bottom iodine phase 
passes to the iodine wash column for phosphoric acid removal before returning to Section I.

The small quantities of $\mathrm{H}_{2} \mathrm{SO}_{4}$ and $\mathrm{SO}_{2}$, remaining in the lower phase product from Section I, react chemically with $H I$ in the feed preheater for the $\mathrm{HI}$ Distillation Column. The product of the reactions are $\mathrm{H}_{2} \mathrm{O}, \mathrm{I}_{2}, \mathrm{H}_{2} \mathrm{~S}$, and $\mathrm{S}$. The quantities involved are so small that the relative amounts of $\mathrm{S}$ and $\mathrm{H}_{2} \mathrm{~S}$ have not been determined. For flowsheeting and cost estimating purposes, it has been assumed that half the sulfur in $\mathrm{H}_{2} \mathrm{SO}_{4}$ and $\mathrm{SO}_{2}$ ends up as $\mathrm{H}_{2} \mathrm{~S}$ and half as $\mathrm{S}$. The $\mathrm{H}_{2} \mathrm{~S}$ will leave the column in the overhead product and the $\mathrm{S}$ is assumed to exit the column with the $\mathrm{H}_{3} \mathrm{PO}_{4}$. The 11quid $\mathrm{S}$ is separated from the $\mathrm{H}_{3} \mathrm{PO}_{4}$ and oxidized back to $\mathrm{SO}_{2}$ in Section II.

\subsubsection{Phosphoric Acid Concentration}

Removal of water from the phosphoric acid is accomplished in tinree stages of vapor recompression-driven flash evaporation. The operating condition of each stage has been modified so as to reduce capital cost for heat exchange. Each stage now operates at a different pressure with the pressure decreasing as the acid concentration increases. The major cost saving came through eliminatior of the heat exchanger which conditioned the evaporator feed. Only the first and last stages require any heat input from the fusion reactor, but a11 three stages require significant quantities of power for vapor recompresslon. A total of $641 \mathrm{Mi}$ of shaft power is required to operate the compressors whereas only an additional 104 ind of themal power at $484 K$ is required from Section $\checkmark$ to heat the high temperature evaporator. Heat is recovered within each evaporation stage from interstage cooling of the six-stage compressor, from the condensation of the compressed steam and from the concentrated phosphoric actd product.

The phosphoric acid concentration step is simple in concept but capital costs of the turbine compressors and heat exchangers are significant in the o erall hydrogen production cost. Even though a considerable reduction in the cost of $\mathrm{H}_{3} \mathrm{PO}_{4}$ concentration has been made, al ternative chemical systems are under continuing investigation with the goal of el iminating $\mathrm{H}_{3} \mathrm{PO}_{4}$ from the process. 


\subsection{HI Decomposition Step (Section IV)}

\subsubsection{Design Considerations}

The HI decomposition step (Section IV of the process) requires the following operations:

- Decompose HI(1) to $\mathrm{H}_{2}(\mathrm{~g})$ and $\mathrm{I}_{2}(1)$

- Separate HI from the I2 and recycle to the decomposer

- Separate $\mathrm{HI}$ from the $\mathrm{H}_{2}$ and recycle to the decomposer

- Scrub the $\mathrm{H}_{2}$ product in preparation for distribution

A simplified schematic flow diagram of Section IV is presented in Figure 5.7-1.

Three process variables dominate the design of Section IV and have a direct impact on the fusion reactor interface. The temperature and pressure of the HI Decomposition Reactor govern the equipment size and amount of recycle through the reactor, whereas the HI-I2 Distillation Column pressure determines the maximum pracess temperature required from the fusion reactor. Variables governing the cleanup of the hydrogen product have a smaller, but still significant, impact on the hydrogen production cost.

\subsubsection{HI Decomposition}

Hydrogen lodide decomposition is accomplished in the HI Decumposition Reactor ( $R-401$ ). The extent of the decomposition reaction is limited by thermedynamic equilibrium. Therefore, to limit the amount of recycle of $\mathrm{HI}$ back through the reactor, process conditions must be chosen so as to give a high conversion per pass through the reactor. Previous studies at the General Atamic Company (10) have demonstrated that when decomposition is carried out under high pressures so that $\mathrm{HI}$ and $\mathrm{I}_{2}$ are present as liquids, a wuch higher decomposition yieid is obtained than with the analogous gas phase decomposition. Selection of the temperature and pressure involve a number of tradeoffs. The critical temperature of HI places an upper limit upon the 


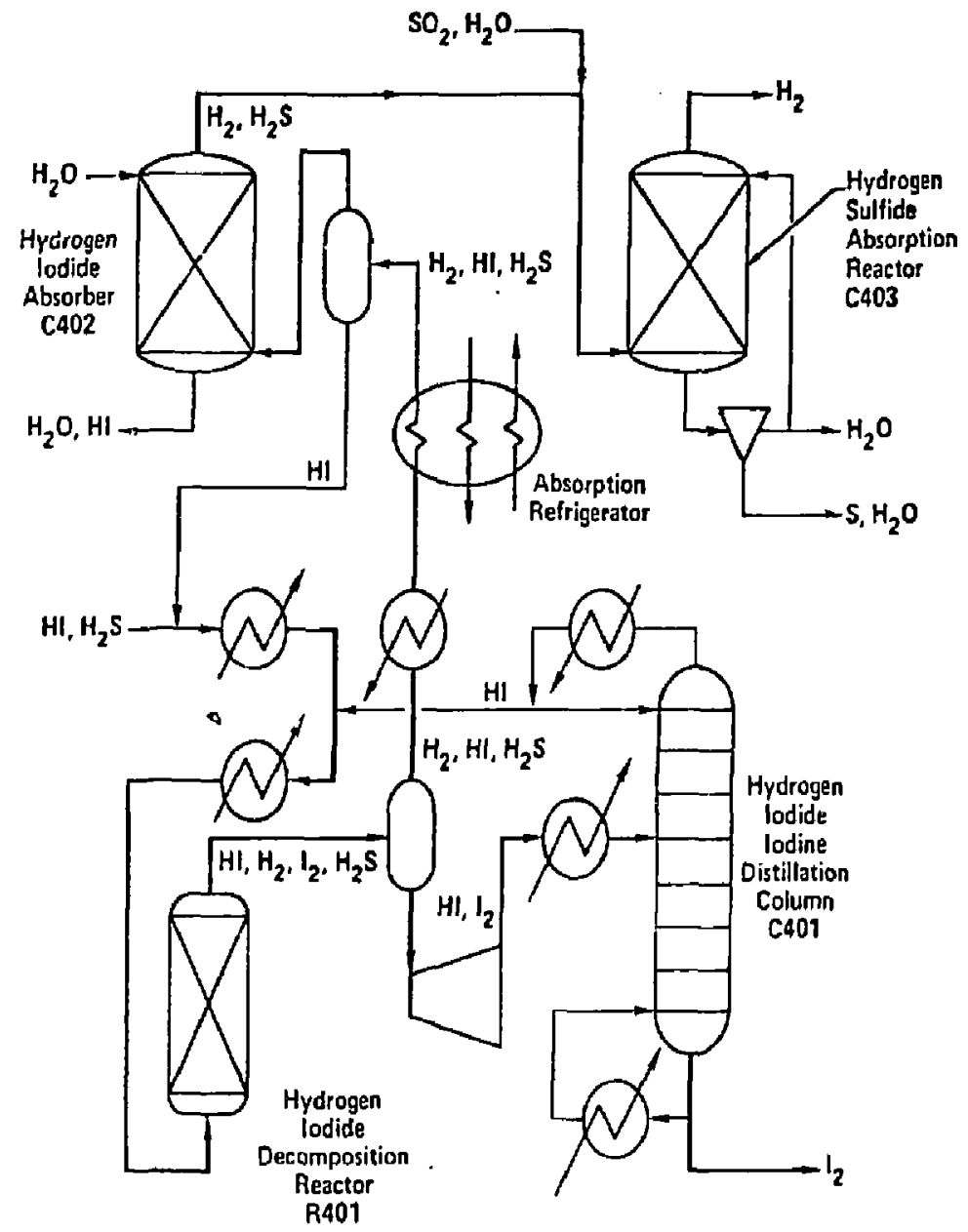

Figure 5.7-1 Schenatic Flow Diagram of Section IV, the HI Decomposition Step 
initial reaction temperature of an adiabatic flow reactor, while the required hydrogen delivery pressure places a lower bound upon the system pressure.

For this system design we still rely upon an adiabatic flow reactor using an activated charcoal catalyst. The recently developed homogeneous catalysis concept (2) hecame available after this year's design base was fixed.

The reactor was sized for a 4-minute residence time. The mild steel vessel is lined with fluorocarbon to protect it from the HI and iodine. The reactor operates at $8.3 \mathrm{MPa}$. the reaction temperature increases from $415 \mathrm{~K}$ at the injet to $424 \mathrm{~K}$ at the outlet due to the slightly exothermic nature of the reaction under these conditions. The majority of the energy required to bring the HI to reaction temperature is supplied by heat reuse within Section IV. only $6 \%$ of the energy $\left(10.9 \mathrm{~m}_{\mathrm{t}}\right)$ must be supplied from the fusion reactor.

A design based upon a continuous stirred tank reactor deserves future consideration. It would require a considerably longer residence time than the adiabatic flow reactor, but the system pressure could be lowered to $5 \mathrm{MPa}$, which may lead to reduced capital costs.

\subsection{3 $\mathrm{HI}-\mathrm{I}_{2}$ Distillation}

The liquid product from the HI Decomposition Reactor passes through a pressure reducing turbine to the HI-I distillation column (C-401). The prescure of the still $(5.1 \mathrm{MPa})$ sets the temperature of the still bottoms at $71^{\circ} \therefore$ The still pressure and temperature may be decreased further, thus decreasing the high temperature heat load on the fusion reactor but at the expense of increased low temperature heat requirements to reheat the still overhead product for recycle to the HI cracker. In addition, the heat now suppifed from the overhead condenser to the evaporative refrigerator and from the bottoms product to the liquid HI heat exchangers, would instead have to be supplied from other sources. 
In addition to the $49 \mathrm{MW}$ required from the fusion reactor helium stream, an additional $36 \mathrm{MN}$ is required at $522 \mathrm{~K}$. This additional heat may be used at a lower temperature because the distillation column is designed with intermediate roboilers. The use of intermediate rebollers increases the cap1tal cost due to the cost of both the bollers and additional trays in the column, but the overall thermal effictency is improved significantly.

The distillation column, constructed from Hastelloy-B clad mild steel, is $2.7 \mathrm{~m}$ in diameter for the bottom $12 \mathrm{~m}$ and expands to $4.7 \mathrm{~m}$ in diameter for the upper $3 \mathrm{~m}$. There are 25 Hastelloy-B trough type trays in the bottom section and 6 in the top. The expanded top section is required by both the higher flow rates and lower density encountered in this section of the column.

\section{7 .4 Hydrogen Cleanup}

The hydrogen from the decomposer is cleaned in three operations. First, the bulk of the hydrogen iodide is removed by condensation. Second, remaining $\mathrm{HI}$ is removed with a water wash. Finally, the trace of $\mathrm{H}_{2} \mathrm{~S}$ is removed by a combination of chemical reaction and water wash.

Tre gaseous product of the HI Decomposition Reactor is cooled in three stages. A heat exchanger removes the high temperature portion of the heat to the power battoming cycle and dumps the low cemperature heat to cooling water. The stream is further cooled from $303 \mathrm{~K}$ to $291 \mathrm{~K}$ via an absorpticn refrigeration system. The $\mathrm{LiBr}$ based refrigeration $(21)$ is driven by waste heat from the condenser of the HI- $I_{2}$ Distillation Column. After condensate separation, only a small quantity of $\mathrm{HI}$ and possibly $\mathrm{H}_{2} \mathrm{~S}$ remain in the hydrogen.

The remaining HI is easily removed via a water wash (C-402). A minimum amount of water is employed because any water added at this point must be removed by distillation in Section III. In the absence of iodine, HI is not corrosive to nonmetallics; therefore, hydrocarbon-lined mild steel is sufficient for this application. Since traces of iodine could enter the HI 
scrub column due to process upsets in the HI condensation system, the lower portions of the column are lined with fluorocarbon. The column is packed with 25-mm ceramic Raschig rings.

Due to the high acidity in the Iower portions of the column, $H_{2} S$ cannot be absorbed. $\mathrm{H}_{2} \mathrm{~S}$ bullds up slightly in the upper section of the column until at steady state, $\mathrm{H}_{2} \mathrm{~S}$ passes on to the $\mathrm{H}_{2} \mathrm{~S}$ removal column $(\mathrm{C}-403)$ at the same rate It enters the $\mathrm{HI}$ scrub column. Since $\mathrm{H}_{2} \mathrm{~S}$ has a relatively low solubility in water, a simple water scrub would require that an excessive amount of water be processed through Section II to reconvert the $\mathrm{H}_{2} \mathrm{~S}$ to $\mathrm{SO}_{2}$. The problem is solved by adding a small amount of $\mathrm{SO}_{2}$ to the $\mathrm{H}_{2} \mathrm{~S}$ absorber. $\mathrm{H}_{2} \mathrm{~S}$ reacts with $\mathrm{SO}_{2}$ in the presence of weter to produce a sulfur slurry. The slurry is concentrated wia a illter with back-flush so only a small amount of water accompanies thr: $\mathrm{S}$ back to Section II where it is sonverted to $\mathrm{SO}_{2}$ via reaction with $\mathrm{SO}_{3}$. The mild steel column, packed with 25-mm ceramic Rashig rings, is hydrccarbon lined to prevent corrosion.

The $\mathrm{H}_{2}$ pressure is dropped to the distribution pressure of $5.1 \mathrm{MPa}$ via a power recovery turbine and thus exits the process.

\subsection{Materials Selection for the Thermochemical Plant}

The corrosive nature of the chemicals involved in the GA aycle has necessitated an extensive materials testing program be carried out duning the process development effort. Since sulfurlc acid is common to other thermochemical cycles and is Industrially significant, other workers have extensively investigated materials for the $\mathrm{H}_{2} \mathrm{SO}_{4}-\mathrm{H}_{2} \mathrm{O}$ system.

\subsubsection{Materials Selection for Section I}

The extensive materlal testing program for the $\mathrm{GA}$ cycle has produced a great deal of data on corrosion in iodine systems $(22)$. Table 5.8-1 presents a summary of the test results. Early results indicated that niobium is impervious to attack by the HI- $\mathrm{I}_{2}-\mathrm{H}_{2} \mathrm{O}$ solutions typical of the main solution reactor, but the most recent work regarding the effect of the $\mathrm{H}_{2} \mathrm{SO}_{4}$ up on 


\begin{tabular}{|c|c|c|c|c|c|}
\hline \multirow{3}{*}{$\begin{array}{c}\begin{array}{c}\text { PAINCIPAL } \\
\text { UNIT-DPERATIONS }\end{array} \\
\text { MAIN SDLUTION BEACTION }\end{array}$} & \multirow{3}{*}{$\begin{array}{l}\text { FLUIDS } \\
+\mathrm{H}_{2} \mathrm{O} \longrightarrow \\
\mathrm{SO}_{4}(55 \mathrm{~m} \times \mathrm{ACID})\end{array}$} & \multicolumn{2}{|c|}{$\begin{array}{l}\text { TEMPEAATUARE } \\
\text { AANGE }\end{array}$} & \multirow{2}{*}{\multicolumn{2}{|c|}{$\begin{array}{l}\text { MATERIAL CANDIDATES FOR: } \\
\text { HEAT EXCHANGERS. VESSELS, PUMPS AND } \\
\text { HARDWARE }\end{array}$}} \\
\hline & & \multirow{2}{*}{$\frac{{ }^{\circ} \mathrm{C}}{125}$} & \multirow{2}{*}{$\frac{K}{398}$} & & \\
\hline & & & & $\begin{array}{l}\text { GLASS-LINED STEEL: } \\
\text { FLUOROCARBOH PLASTICS } \\
\text { \& ELASTOMERS: }\end{array}$ & $\begin{array}{l}\text { CERAMHCS - } \mathrm{SIC}_{1} \mathrm{Al}_{2} \mathrm{O}_{3} \text {, CARBON } \\
\text { IMPERVIOUIS GRAPHITE } \\
\text { TANTALUMM }\end{array}$ \\
\hline$I_{2}$ AND $\mathrm{H}_{2} \mathrm{O}$ SEPARATION & $\mathrm{HI}_{x}+\mathrm{H}_{3} \mathrm{PO}_{4}$ & $120-158$ & $393-431$ & $\begin{array}{l}\text { GLASS-LINED STEEL; } \\
\text { TANTALUM-LINED STEEi; }\end{array}$ & $\begin{array}{l}\text { HASTELLOY B-2; } \\
\text { FLUOROCARBOH PLASTICS }\end{array}$ \\
\hline$I_{2}$ AECYCLE & $I_{2}$ & 120 & 393 & HASTELLOYS B-2, G, C-276; & GLASS \\
\hline $\begin{array}{l}\text { DECOMPOSITION OF } \\
\text { LIQUID HI }\end{array}$ & $H I_{x}\left(\operatorname{LOW~} \mathrm{H}_{2} \mathrm{O}\right): \mathrm{I}_{2} ; \mathrm{H}_{2}$ & 120 & 393 & $\begin{array}{l}\text { HASTELLOY B-2; } \\
\text { FLUOROCARBON PLASTICS; }\end{array}$ & $\begin{array}{c}\text { GLASS-LIMEO STEEL: } \\
-\end{array}$ \\
\hline
\end{tabular}

Table 5.8-1 Material candidates for handling process fluids containing $\mathrm{HI}_{x}$ and $\mathrm{I}_{2}$ 
$\mathrm{H}_{2} \mathrm{SO}_{4}$ upon the system questions the use of nlobium in this portion of the process. Tantalum can be substituted for the niobium, at higher cost, but this has not been done in the present equipment design.

Although glass-lined steel is an ideal materiai for use with the $\mathrm{HI}-\mathrm{I}_{2}-\mathrm{H}_{2} \mathrm{O}$ system, it is unavailable in the equipment sizes required for the TMR powered plant. Fluorocarbon-lined steel performs the same function and is available in the desired equipment sizes.

\subsubsection{Materials Selections for Section II}

Materials selections need to be made for the following process units for Section II:

- Isobaric Concentrator

- Low Pressure Distillation Column

- $\mathrm{H}_{2} \mathrm{SO}_{4}$ goiler

- Fluidized Bed Decomposer

- Decomposer Recuperator

- Decomposer Cooler

Table 5.8-2 presents a summary of the material investigations by $G A(22)$ for the sulfuric acid sections of the process.

\section{$\mathrm{H}_{2} \mathrm{SO}_{4} \underline{\text { Boiler }}$}

Materlals problems are similar for the Isoboric Concentrater, the Low Pressure Distlllation Column, and the $\mathrm{H}_{2} \mathrm{SO}_{4}$ Boller. The main problem is to provide a heat exchanger that is tolerant of hot concentrated sulfuric acid. All knuwn metallic heat exchanger materials (except for expensive noble metals such as $\mathrm{Au}$ and $\mathrm{Pt}$ ), are severely corroded by these $\mathrm{H}_{2} \mathrm{SO}_{4}$ solutions above temperatures of $500 \mathrm{~K}$. A number of ceramic and intermetaljic materials have been tested in hot concentrated $\mathrm{H}_{2} \mathrm{SO}_{4}$ at $633-693 \mathrm{~K}$ in recent years at $\operatorname{LLNL}_{L}(23,24)$ and at Westinghouse $(25)$. The top candidate materials from both corrosion resistance and heat exchanger design standpoints are the following: 


\begin{tabular}{|c|c|c|c|c|c|c|}
\hline \multirow{2}{*}{$\begin{array}{l}\text { PAINGIPAL } \\
\text { UNIT OPEAATION }\end{array}$} & \multirow{2}{*}{\multicolumn{2}{|c|}{ FLUIOS }} & \multicolumn{2}{|c|}{$\begin{array}{l}\text { APPROXIMATE } \\
\text { FLUIO TEMPERATUAES }\end{array}$} & \multirow{2}{*}{\multicolumn{2}{|c|}{$\begin{array}{l}\text { MATERIAL CANDIDATES FOR: } \\
\text { HEAT EXCHANGERS, VESSELS, PUMPS } \\
\text { AND OTHEA HARDWARE }\end{array}$}} \\
\hline & & & \multirow{2}{*}{$\begin{array}{l}{ }^{\circ} \mathrm{C} \\
125\end{array}$} & \multirow{2}{*}{$\frac{{ }^{\circ} K}{398}$} & & \\
\hline MAIN SOLUTION REACTION & $\begin{array}{l}\mathrm{SO}_{2+}^{+} \\
\mathrm{HI}_{\mathrm{x}}+\end{array}$ & $\overrightarrow{\mathrm{H}_{2} \mathrm{O}}$ & & & $\begin{array}{l}\text { GLASS-LINED STEEL: } \\
\text { FLUOROCARBON } \\
\text { PLASTIES \& ELASTOMEAS: }\end{array}$ & $\begin{array}{l}\text { CEAAMICS-SiC } \\
\text { Al2 } \mathrm{O}_{3}, \text { CARBON: } \\
\text { IMPEFVIOUS GRAPHITE } \\
\text { TANTALUM }\end{array}$ \\
\hline GONGENTRATION & $\mathrm{H}_{2} \mathrm{SO}_{4}$ & $65-65 \mathrm{mt} \times$ & $95-150$ & $368-423$ & $\begin{array}{l}\text { HASTELLOYS B-2 } \\
\text { OA C-276 } \\
\text { IMPERVIOUS GRAPHITE }\end{array}$ & $\begin{array}{l}\text { GLASS OR } \\
\text { BRICK-LIHED STEEL }\end{array}$ \\
\hline CONCENTRATION & $\mathrm{H}_{2} \mathrm{SO}_{4}$ & $65-75 \mathrm{kr} *$ & $150-180$ & $423-453$ & $\begin{array}{l}\text { HASTELLOYS B-2 } \\
\text { DR C-276 } \\
\text { IMPERVIOUS GRAPHITE }\end{array}$ & $\begin{array}{l}\text { GLASS OR } \\
\text { BRICK-LINED STEEL }\end{array}$ \\
\hline CONGENTRATION & $\mathrm{H}_{2} \mathrm{SO}_{4}$ & $75-98$ wt $x$ & $180-420$ & $453-693$ & BRLCK-LINEO STEEL: CAST & $=0-14 m \times 5 i$ \\
\hline $\begin{array}{l}\text { VAPOR FORMATION } \\
\text { AND OECOMPOSITION }\end{array}$ & $\mathrm{H}_{2} \mathrm{SO}_{4}$ & $\overline{\mathrm{H}_{2} \mathrm{O}+\mathrm{SO}_{3}}$ & $330-600$ & $603-873$ & $\begin{array}{l}\text { BRICK-LINED STEELL CAST } \\
\text { SILICIDE COATINGS ON STI }\end{array}$ & $\begin{array}{l}\text { O-14 WT XSI } \\
\text { EL: HASTELLLY E }\end{array}$ \\
\hline VAPOR OECOMPOSITION & $\begin{array}{l}\mathrm{SO}_{3}+ \\
\mathrm{H}_{2} \mathbf{O}\end{array}$ & $\overrightarrow{1 / 20_{2}}$ & $600-850$ & $873-1123$ & INCOLOY BOOH WITH ALUM & MIDE COATING \\
\hline
\end{tabular}

Table 5.8-2 Candidates construction materials for sulfuric acíd 


\section{- Siliconized SiC}

- "CrSi2" coated Incoloy-800

- Durichior-51 (Fe-14\% $\$ 1-4 \% \mathrm{Cr}$ )

All of these naterials depend upon the development of a corrosion resistant $\mathrm{SiO}_{2}$ scale on the surface to provide protection against corrosion by $\mathrm{H}_{2} \mathrm{SO}_{4}$. simflarly, it is well known that pure siffea glass $\left(\mathrm{SiO}_{2}\right)$, such as in the form of silica brick, is inert to corrosion by $\mathrm{H}_{2} \mathrm{SO}_{4}$.

SiC currentiy presents the best prospect as a heat exchanger material. Sfliconized SiC (a two-phase composition consisting of a mixture of SiC and Si) is produced at the Norton $(26)$ and Carborundum $(27)$ companies and is especially suited for this type of application. This type of material, which contains about a 10-15\% excess of silicon metal, is impervious to gases, has a high thermal conductivity, high strength, good thermal shock resistance, and can be fabricated in complex shapes and bonded together to form heat exchanger assemblies (28). Corrosion testing of S1C for $1121 \mathrm{~h}$ and Si for 592 h i it $97 \%$ $\mathrm{H}_{2} \mathrm{SO}_{4}$ at $673 \mathrm{~K}$ at the Lawrence Livermore National Laboratory showed no evidence of corrosion $(23)$, thus confirming the corrosion resistance of both SiC and 51 for this application.

Specimens of Incoloy-800 coated with chromium silfcide of nominal composition CrSiz were tested for corrosion for $240 \mathrm{~h}$ at $673 \mathrm{~K} \mathrm{in} 978 \mathrm{H}_{2} \mathrm{SO}_{4}$ at the Lawrence Livermore National Laboratory $(24)$ and found to show a very low rate of corrosion (extrapolated weight loss rate of $15 \mathrm{mg} / \mathrm{cm}^{2}-y$ ). The coatings were about $120 \mathrm{~m}$ thick, unifoim in thickness, weil-bonded to the substrate, and without evidence of fractures. The coatings were prepared by Dr. Charles M. Packer of Lockheed Missiles and Space Company of Paio Al to, California, using a slurry coat and rapid melt technique. Al though the above results are preliminary in nature, they are encouraging in that a conventional heat exchangel material such as Incoloy-800 can be protected against corrosion by a coating prccess. 
Durichlor-51 is a commercial high silicen cast iron material that is yet another candidate as a heat exchanger or intafner material. It is basically an intermetallic compound with a composition of approximately $\mathrm{Fe}_{3} \mathrm{Si}$ and, as such, presents the disadvantages common to most intermetallics of poor ductility, low tensile strength, and poor machining and fabrication characteristics. Also, being a cast material, the control of internal porosities and non-uniformities present production problems. Nonetheless, with proper quality control and with good engineering design and practices, these problems can be controlled. From a corrosion standpoint, tests of up to $524 \mathrm{~h}$ on Durichior-51 223 ) have shown only a moderate amount of attack 15 micron surface penetration); but very importantly, corrosion appears to proceed very uniformly over the surface of this material. It therefore seems reasonable to extrapolate to a lifetime of the order of $5 y$ for this application. In contrast to Durichior-51, duriron is another high silicon cast iron alloy that shows a rather irregular corrosion behavior with grain pullouts, corrosion pits, and spallation in similar $\mathrm{H}_{2} \mathrm{SO}_{4}$ corrosion tests at $673 \mathrm{~K}(23)$.

In view of the developments thus far, our choice of material is siliconized $\mathrm{SiC}$ for the $\mathrm{H}_{2} \mathrm{SO}_{4}$ heat exchangers. We select silica brick as a liner material for the vesseis, both because of the inertness of silica to corrosive attack by sulfuric acid, and to provide tleemal insulation so that more conventional materials (e.g., Tefion-lined steel) can be used for the vessel $1 \cdot 271$. We seiect Durichlor-51 for the bodias of the liquid $\mathrm{H}_{2} \mathrm{SO}_{4}$ pumps.

\section{Fluidized Bed Decomposer}

The main materials problem in the Fluidizeo Bed Decomposer is selection of a heat exchianger material to meet corrosion resistance and creep strength requirements.

Corrosion tests on a number of heat exchanger alloys for $\mathrm{H}_{2} \mathrm{SO}_{4}$ vapor decomposers have been carried out at JRC Ispra and at the General Atomic company at temperatures in the $773-1173 \mathrm{~K}$ range. Their results $(29)$ indicate that as bare uncoated alloys, Incoloy-800H and Inconel-625 provide the best 
materials with anticipated lifetimes of a few years. A substantial gain in 1 ifetime can be achieved by using an aluminide-coated Incoloy-800H on the surface exposed to the decomposing $\mathrm{SO}_{3}$ gas. This gives an unusually stable coating-substrate combination that stabilizes in coating thickness and weight change after an exposure of 200-300 hours to the gaseous $\mathrm{H}_{2} \mathrm{SO}_{4}$ products $(25)$. Corrosion protection is apparently afforded by an $\mathrm{Al}_{2} \mathrm{O}_{3} \mathrm{f} 41 \mathrm{~m}$, and imperfections in the coating are salf-healing. The useful life of aluminide-coated Incoloy$800 \mathrm{H}$ for this application is believed to be of the arder of 20 years. On the high pressure helium side, corrosion is not a problem.

From a consideration of creep strength, cost, and fabrication issues, Incone1-617, Inconet-625, and Incoloy-800 (or Incoloy-800H) appear to provide the best al ternatives. Stress rupture and creep properties for InconeT-625 and Incoloy -800 are comparable $(30)$. Al though creep strength data are not available for Inconel-617, it shows 1000-hour stress rupture strengths that are three times higher $(30)$ than for the other two alloys. Thus, ixtrapolations of the available data for Incone1-625 and Incoloy-800 suggest a tenstle creep strength for $1 \%$ creep in 100,000 hours of $2000 \pm 50 \% \mathrm{psi}\left(1.1 \times 10^{7} \mathrm{~Pa}\right)$ at $1100 \mathrm{~K}$ and $1200+30 \% \mathrm{ps} 1\left(8.2 \times 10^{6} \mathrm{~Pa}\right)$ at $1150 \overline{\mathrm{K}}$. Ke estimate the corresponding values for Inconel-617 to be $6000+50 \% \mathrm{psf}\left(4.1 \times 10^{7} \mathrm{~Pa}\right)$ at $1100 \mathrm{~K}$ and $3600+30 \%$ psi $\left(2.4 \times 10^{7} \mathrm{~Pa}\right)$ at $1150 \mathrm{~K}$ based on the argument that the creep strengths scale as a fraction of the long-term creep rupture data simflar to Inconel-625 and Incoloy-800. Al though no creep data are available for Incoloy-800H, it is a material that has been designed for higher strength than Incoloy-800 and should give a better performance.

From a consideration of both corrosion and creep strength we select Incoloy-80OH as ine heat exchanger materlal for the Fluidized Bed Decomposer. A minimum wall thickness $3 \mathrm{~mm}$ is required to maintain materiat intngrity after alTowances for $0.5 \mathrm{~nm}$ corrosion penetration. An aluminide protective coating is recommended on the $\mathrm{SO}_{3}$ side of tha heat exchanger to obtain a longer equipment life.

Incoloy-800H is al 50 the material of choice for constructing the vesse? and gas distributor for the Fluidized Bed Decomposer. Alternatively, the walls 
could be constructed of silica brick backed with 376 stainiess steel. For staintess steel to be successfuily employed it must be maintained above the condensation temperature of șlfuric acid (680K).

\section{Decomposer Recuperator}

The main materials problem for the Decomposer Recuperator is for the Heat Exchanger, and as was the case for the Fluidized Bed Decomposer, corrosion and long-term creep strength are the main considerations. Temperatures are sufficiently lower here $(1100 \mathrm{~K})$ that the problems are less severe. Therefore, an aluminide coating should not be needed. We select incoloy-800 at a wall thickness of $3 \mathrm{~mm}$ as the preferred material with Inconel-617 as a backup for the Decomposer Recuperator heat exchanger. Selections for the vessel walls are either silica brick-lined 316 stainless steel or Incoloy-800H.

\section{Decomposer Cooler}

Transport piping from the Decomposer Recuperator to the Decomposer Cooler would be made from Incoloy 800H. The Decomposer cooler heat exchanger is an integral part of the acid concentration system and the heat exchanger tubes would be made from siliconized ste.

\section{Surmary of Materials Selections for Section II}

The selection of materials for Section II are summarized below in Table 5.8-3. 
Table 5.8-3 Summary of Materials Selections for Heat Exchanger and Vessel Materials for Section II of the GA Thermochemical Cycle

PROCESS UNIT

Concentrator

$\mathrm{H}_{2} \mathrm{SO}_{4}$ Vaporizer

Fluidized Bed Decomposer

Decomposer Recuperator

Decomposer Cooler
HX MATERIALS

Silfconized SiC tubing, Ourichtor-51 pumps

Siliconized Sic tubing, Durichior-51 pumps

Aluminide-coated Incoloy-800H

Incoloy-800H

Siliconized SiC tubing
VESSEL MATERIALS

Sillea brick liner on

Teflon-lined mild steel

sllica brick liner on Teflon-lined mild steel

Incoloy-800H, or silica brick liner on 316 S.S.

Incoloy-800H, or silica brick liner on 316 S.S.

Vessel is integral part of concentrator. 


\subsubsection{Material Selection for Sections III and IV}

Material selection for Sections III and IV is similar to that selected for Sections I and II. The information in Table 5.8-I is applicable to the jodine-HI regions of Sections 111 and IV. Phosphortc acid adds no new complexity except in the high temperature portions of the process, acid brick is necessary as a thermal protection for teflon liners. In addition, Hastelloy $C$ has been recommended (31) for use with bolling concentrated phosphoric acid.

\subsection{Safety Considerations}

The main safety issues involve the control, handling, and containment of tritium, liquid lichium lead, and sulfuric acid. The safety issues regarding tritium and liquid lithlum were reviewed and discussed in some detail in the 1980 report (19), and it was concluded that adequate controls were designed into the system to raintain proper safety. We have applied similar consideratoins in the current designs, including particular attention to both residual and accidental leakages of tritium into the environment or product, tritium inventories in the system, and potential problems of liquid lithium flres. We feel that the safety issues have been wall met, and many of the details have been covered in this report. He refer the reader to previous reports for further detafls.

In regard to safety of sulfuric acid, it is important that conservative designs be maintained on the vessels and piping containing hot liquid and gaseous sulfuric acid and its deconiposition products, since sulfuric acid introduced into the environmert is a serious health hazard. We feel that we have taken adquate measures in our design studies, and recognize further that the sulfuric acid industry has been a large and well-established industry and one that we can draw on for future design information as needed for assuring a safe plant. 


\subsection{Plant Layout and Piot Plan}

\subsubsection{Plant Layoùt}

A complete plant process layout, assembling all of the sections, was prepared for a previous version of a ThR driven water-splitting plant $(1)$ and is given Earlfer in the report in Figure 5.0-1, complete with important process parameters and labels on key process sections and on process units. The legend describes the symbolic representation used. Generally we have attempted to arrange the hignest temperature processes at the top of the figure and the lower temperature processes at the bottom. At the immediate left is the Tandem Mirror Fusion driver and the associated helium coolant streams operating turbo-generators and process heat exchangers as a topping cycle and bottoming into a steam-Rankine cycle for additional electricity generation.

A larger version of this complete process flow diagram and flowsheet are avallable upon request. However, this reduced-size figure has been included to help one grasp the overall picture of the Fusion/Synfuels Process concept.

The MARS version of the flowsheet has not been integrated into a similar one full layout but simplified flowsheets for each section have been presented in the text of this section. The composite flowsheet still serves the purpose of presenting the scale of the total thermochemical process.

\subsubsection{Plot Plan}

An artist's conceptual drawing of the plot plan as given previously(1) report is shown in Figure 5.10-1. Changes in this yea:'s design did not materially affect space requirements so this plot plin still gives a rough idea of the approximate land area and relative sizes of the TMR nuclear island, turbine-generator, steam generator and process heat exchanger building, as well as the rest of the chemical plant. He conclude from the plot plan that this plant is quite compact, and raises no new issues regarding heat transport distances, safety, etc. 


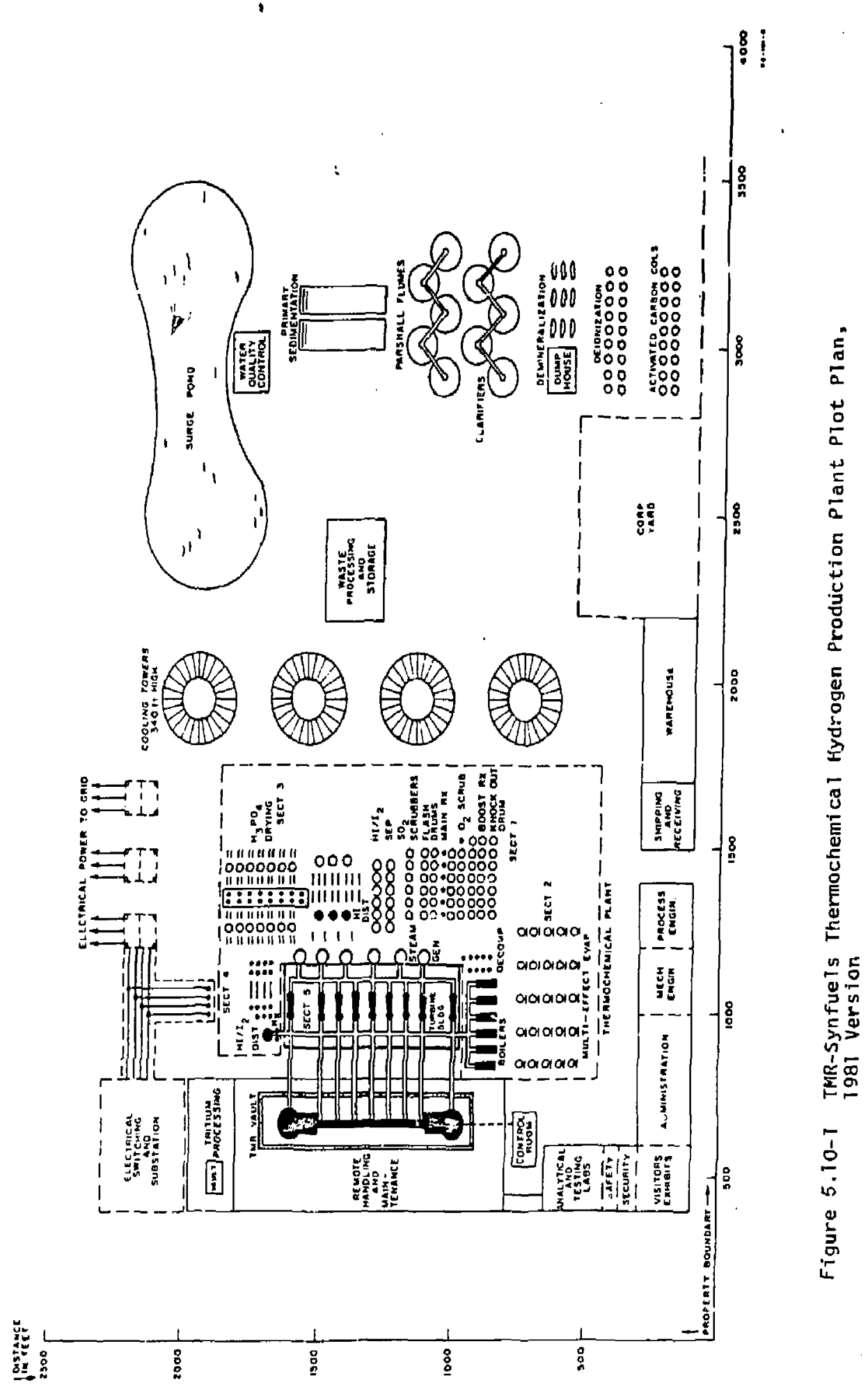




\section{References for Section 9.0}

1. R. W. Werner, et al., "Conceptual Deslgn Study FY 1981, Synfuels from Fuston using the Tandem Mirror Reactor and a Thermochemical Cycle to Produce Hydrogen," Lawrence Livermore National Laboratory, Report UC10-19311, February 9, 1982.

2. S. H. Norman, G. E. Besenbruch, L. C. Brown, D. R. O'Keefe, and C. L. Allen, "Thermochemical Water-Splitting Cycle, Bench-Scale Investigations and Process Engineering, Final Report for the Feriod Ending February 1977 through December 31, 1981," DOE Report DJE/ET/26225-1, General Atomic Company Report GA-A16713, May 1982.

3. G. E. Besenbruch, K. H. McCorkle, J. H. Norman, D. R. O'Keefe, J. R. Schuster, and M. Yoshimoto, "Hydrogen Production by the GA Sulfur-Iodine Process, A Progress Report," Hydrogen Energy Progress, Proceedings of the 3rd Horid Hydrogen Energy Conference, Tokyo, Japan, 23-26 June 1980, ToT. I edited by T. N. Veziroglu, K. Fueki and T. Ohta, Pergamon Press, oxford, 1980, P. 243.

4. J. H. Morman, G. E. Besenbruch, and L. C. Brown, "Solar Production of Hydrogen using the Sulfur-Iodine Thermochemical Water Splitting Cycle, Finat Report," General Atomic Company Report GA-C-16493.

5. J. H. Norman, "Studies of the Sulfur-Iodine Thermochemical Water-Splitting Cycle," Hydrogen Energy Progress, Proceedings of the 3rd Horid Hydrogen Energy conference, rokyo, Japan, 23-26 June 1980, Vo1. 1, edited by T. N. Vezirogiu, R. Fueki, and T. Ohta, Pergamen Press, Oxford, 1980, p. 277.

6. D. R. O'Keefe and J, H. Norman, "The Liquid Hydrogen lodide Decomposition Process Step for Water-Splitting Applications," Hydrogen Energy Progress, Proceedings of the srd World Hydrogen Energy Conference, Tokyo, Japan, 23-26 June 1980, Vol. 1, edited by T. N. Veziroglu, K. Fueki, and T. Ohta, Pergamon Press, 0xford, 1980, p. 277.

7. F. F. Rupert, "A Study of the System Hydrogen Chioride and Water," J. Am. Chen. Soc. 31, 851 (1909).

8. "Thermochemical Water-Splitting Cycle, Bench-Scale Investigations and Process Engineering, Annual Report for the Period February through December 31, 1977," General Atomic Company Report, GA-14950, April 1978.

9. L. N. Horsley, "Azeotropic Data III," Advances in Chemistry Series, Vo1. 116, American Chemical Society, hashington, D.C., 1973.

10. D. R. O'Keefe and J. H. Norman, "The Liquid Hydrogen Iodide Decomposition Process Step for Water-Splitting Applications," Hydrogen Energy Progress, Proceedings of the 3rd Horld Hydrogen Energy Conference, Tokyo, Japan: 23-26 June 1980, Vol. I, edfted by T. N. Veziroglu, K. Fueki, and T. Onia, Pergamon Press, oxford, 1980, p. 277. 
11. A. F. Ruabinina and V. A. Oshman, "Thermal Decomposition of Aqueous Sulfur Dioxide Solutions," Tr. Ural. Lesotekh, Inst. 1972, No. 28, 182 (Russ), Chem. Abstracts 79, 58115p, 1973.

12. "JANAF Thermochemical Tables," Dow Chemical Company, Midland, Michigan, September 30, 1977.

13. F. W. Glaugue, et al., "Thermodynamic Properties of Aqueous Sulfuric Acid Solutions and Hydrales from 15 to 300K," J. Am. Chem. Soc. 82, 62 (1960).

14. "Thermochemical Water-Splitting Cycle, Bench-Scale Investigations and Process Engineering Annual Report for the Period October 1, 1978 through September 30, 1979," DOE Report GA-A15788, General Atomic Company, March 1980.

15. M. Coombs, et al., "High-Temperature Ceramic Heat Exchanger, Final Report, juty 1979," AiResearch Manufacturing Company of Californla, Torrance, CA, Report FP-1127, Research Project 545-1, report prepared for Electric Power Research Institute, Palo Aito, CA. R. H. Richman, EPRI Project Mgr.s 1979.

16. R. H. Perry and C. W. Chillton, editors, "Chemical Engineers' Handbook," 5th edition, MCGraw-H H17, New York, 1973, p. 10-21.

17. "Geml ins Handbuch der Anorganischen Chemie, Schwefel, System Number 9," Velag Chemie, GHbH, Weinhein/Bergstrasse, West Germany, 1960, p. 662.

18. E.R.G. Eckert and R. M. Drake, "Analysis of Heat and Mass Transfer," McGraw-Hill, New York, 1972, D. 562.

19. R. W. Werner, et al ,, "Synfuels From Fusion - Producing Hydrogen With The Tandem Mirror Reactor and Thermochemical Cycles," Lawrence Livermore National Laboratory, Report UCID-18909, VoI. I and II, January 21, 1981.

20. "HTGR Thermnchemical Water-Splitting for Hydroge.. Production, Annua? Report for the Period January 1, 1975 through December 31, 1975," General Atomic Company Report GA-A13800, January 31, 1976.

21. F. J. Evans, Jr., "Equipment Design Handbook for Refinery and Chemical Plants," second edition, Vol. 1, Gulf Publishing Co., Houston, TX, 1979, PP. 184-191.

22. P. W. Trester and H, G. Staley, "Assessment and Investigation of Containment Materfals for the Sulfur-Iodine Thermochemical Water-Splitting Process for Hydrogen Production, Fina? Report (July 1979-December 1980)," Gas Research Institute Report, GRI-80/0081, May 1981.

23. 0. H. Krikorian, "Material Corrosion Studies for a SuTfuric Acid Vaporizer," Lawrence Livermore National Laboratory Report UCRL-81856, october 27, 1978. 
24. O. H. Krikorian, "Corrosion Testing of Materials in Hot Concentrated sulfuric Acld, "Lawrence Livermore National Laboratory Report UCRL-83411, September 27, 1979.

25. R. L. Ammon, G. Yatsko, A. Inwin, and G. H. Furbman, "Materials Consideration for the Westinghouse Sulfur Cycle Hydrogen Production Process, "unpub?ished paper presented at the Second World Hydrogen Energy Conference, Zurich, switzerland, 21-24 August 1978.

26. M. L. Torti, J. W. Lucek, and G. Q. Heaver, "Densified Silicon Carbide An Interesting Material for Diesel Applications," Technical paper Series 780071, Society of Automotive Engineers Congress and Exposition, Detrolt, February 27 through March 3, 1978. See also brochures of the Norton Company, Korchester, Massachusetts on "Noral ide Advanced Ceramics," and "Ceramics for Energy."

27. Edwin Craft, Carborundum Compariy, Niagara Falls, New York, private communication regarding bending of KT-Silicon carbide to form U-tubes, October 1979.

28. T. N. Tiegs, "Materials Testing for Solar Thermal Chemical Process Heat," Oak Ridge National Laboratory, Oak Ridge, TN, Report ORNL/TM-7833, October 1981.

29. O. H. Krikorian, "Materials Probiems in Production, Transport and Storage of Hydrogen," Livermore National Laboratory Report, UCRL-83771, January 2, 1980.

30. Engineering Alloys Digest, Inc., Upper Montclair, New Jersey: Filing code Ni-179, Inconel 3lloy 617, September 1972; Filing code Ni-121, Inconel alloy 625, February 1967; and Filing code 55-136, incoloy alloy 800, September 1972.

31. 3. H. Perry, editor, "Chemical Engineers' Handbook," 3rd edition, McGraw Hi17. New York, 1950, D. 1507.

32. R. W. Herner, et. aT., "Synfuels From Fusion Using the Tandem Mirror Reactor and a Thermochemical Cycle to Produce Hydrogen," Lawrence Livermore National Laboratory, Report UC1D-19609, November 1, 1982.

33. A. A. Strub and G. Imarisio, Eds., Ir Proc, Inst. Seminar, "Hydrogen as an Energy Vector," Brussels Belgium, February 1980. Publ ished by Durdredrt, Holland, 1980. 


\section{SECTIUN 7.0 \\ PRELIMINARY COST ESTIMATES \\ Contributor: \\ L. Brown}

\section{TABLE OF CONTENTS}

Section

Description

Page

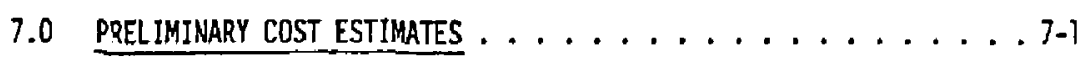

7.1 THE ECONOHIC BASIS ...................... . . . .

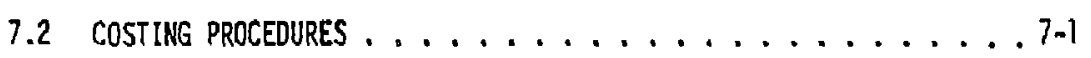

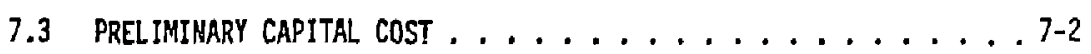

7.3.1 Main Solution Reaction Step (Section I) ....... 7-2

7.3.2 $\mathrm{H}_{2} \mathrm{SO}_{4}$ Processing Step (Section II) . . . . . . . 7-4

7.3.3 HI Concentration Step (Section III) . . . . . . . 7-4

7.3.4 HI Decomposition Step (Section IV) .......... 7-7

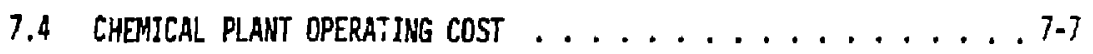

REFERENCES ............................ . . . 
SECTIOH 7.0

\section{List of Tables}

Table

Page

7.3-1 Preliminary Capital Costs for Section I - M\$, July 1980 . . . 7-3

7.3-2 Preliminary Capital Costs for Section II Based on the Joule Boosted Decomposer - M\$, July $1980 \ldots$. . . . . . . 7-5

7.3-3 Preliminary Capitai Costs for Section III - M\$, July 1980 . . 7-6

7.3-4 Prelfininary Capital costs for Section IV - M\$, July 1980 . . . 7-8

7.4-1 Estimated Operating Cost of the Chemical Plant

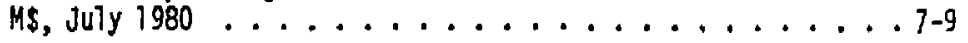




\subsection{PRELIMINARY COST ESTIMATES}

Installed equipment costs and direct operating costs were estimated for the chemical plant as matched to the MaRS blanket. The plant is based on a TWR with a two temperature zoned blanket and a Fludized Bed Decomposer (FBO).

\subsection{The Economic Basis}

We present costs baseí on constant, July 1980 dollars, and use currentiy available chemical plant technology. Since the chemical portion of the plant will be manpower intensive and cannot be operated with as few people or as Iittie supplies or maintenance as in an electric power plant, we have used chemical plant experfence (1) in estimating all labor costs.

\subsection{Costing Procedures}

The chemical industy bas developed considerable expertise in estimating the capital cost as well as the projected operating costs of their respective plants.

Costs for the Chemical Plant and the power systems interface are abtained by standard chemical engineering costing techniques. These costing techniques are based upon using actual construction experience from many chemical plants tr. predict capital and operating costs from FOB equipment costs. The new reference work by Peters and Timmerhaus ( 1$)$ was used to augment the oider Guthrie methods $(5,6)$ both for estimating the FOB costs of equipment, as well as deriving from the FOB cost estimates of the installed direct capital cost, the tatal plant investment and the operating cost. Where standard works coutd not provide capital costs, as in most of section II and the power recovery systems, vendor estimates or other special sources of FOB cost da ta were used. The Industry standard, Marshall and Swift (M\&S) ${ }^{(7)}$, equipment cost index was used to reduce all costs to the same basis, July 1980.

It is recognized that some of the best costing techniques are maintained as proprietary by A\&E, chemical and oil companies. A proprietary costing method, available at $G A$ was used to spot check costs for a representative number of items. No overall bias could be observed although vartations 
between different types of equipment were noted.

We bel feve that our cost estinates are weli within our goal of $\pm 30 \%$ accuracy.

\subsection{Preliminary Capital Cost}

\subsubsection{Mafn Solution Reaction Step (Section I)}

The simplified schematic of Section I was presented in Figure 5.3-1. Table 7.3-1 presents a detafled list of the equipment required for performing the main solution reaction step, together with size and cost data. Witi the exception of the Heat Exchanger Reactor (R-101), all items have been costed by the Guthrie arethod, $(5,6)$

The structural material used throughout Section I is mild steel. If other than dry $\mathrm{SO}_{2}$, exygen and or water are present, the steel must be protected by an approprlate coating or lining. Although spray on hydrocarbon based coatings are adequate when moist $\mathrm{SO}_{2}$ is present, liners of bulk fluorocarbon are specified when $\mathrm{H}_{2} \mathrm{SO}_{4}$, $\mathrm{HI}$ or I2 are present. The installed cost of ffuorocarbon 11 nings is estimated to be $\$ 1100 / \mathrm{m}^{2}$.

The Heat Exchanger Reactor is unique because of the materiai involved, niobium. The $\$ 220 / \mathrm{kg}$ cost of the niobium tubing dominates the reactor cost. Added to the \$15.8 cost of the tubing is an appropriate amount for installation of the tubing (\$3.2M), plus the FOB cost of the equivaient mild steel heat exchangers $(\$ 1,2 N)$, giving an $F O B$ cost of $\$ 20.24$. Installation cost was estimated from the cost of the equivalent mild steel hent exchanger since nlobium is required only for the heat transfer surfaces.

The Guthrie method allows specification of the piping materia?s separate from the specification of tie materials of construction of the equipment. Either mild steel or standard fluorocarbon lined mild steel piping was specified as appropriate. Pumps are either cast iron for water, or cast iron with a molded fluorocarbon liner for corrosive solutions.

Since Section I operates essentially as six systems in parallel, 83\% of production capacity may be maintained if any one system is down for repairs. 
Table 7-3-1 - Prel1minary Capital Coats for Sectlon I ${ }^{\mathrm{a}}$ - Muly 1980

\begin{abstract}
Itram
Ho.
Ciol Primary scrubbing reactor

c102 Lower phase $\mathrm{SO}_{2}$ scrubber

c103 Boost reactor

c104 Secondary sorubbing reactor

S101 High pressure Flash drum

5102 LoH pressure rlash drum

S105 Secondary water knockout drum

F.101 Heat exchanger reactor

E101 SU, neat exchanger

E102 Sec. III water heat exchanger

Pin 1 Hater fead pumb

P yo 3 Reactor Feed pump from c10

Piou lodine reed purap

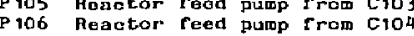

TE101 O power reocyery turbine

TE10 3 I ad ine power recavery turb1r

Total Cap1tal Cost

\begin{tabular}{|c|c|}
\hline $\begin{array}{l}\text { Paraliol } \\
\text { Uiilts }\end{array}$ & $\begin{array}{l}\text { Diameter } \\
\text { Meters }\end{array}$ \\
\hline $\begin{array}{r}-6 \\
6 \\
6 \\
6\end{array}$ & $\begin{array}{l}3.8 \\
5.9 \\
5.9 \\
4.5\end{array}$ \\
\hline $\begin{array}{l}6 \\
6 \\
6 \\
1\end{array}$ & $\begin{array}{l}3.6 \\
4.2 \\
3.0 \\
3.0\end{array}$ \\
\hline 6 & 1.8 \\
\hline $\begin{array}{l}6 \\
2 \\
3\end{array}$ & $\begin{array}{l}1.7 \\
1.1 \\
1.2\end{array}$ \\
\hline $\begin{array}{l}6+1 \\
6+1 \\
6+1 \\
6+1 \\
6+1\end{array}$ & $\begin{array}{l}\bar{z} \\
\bar{z} \\
\bar{z}\end{array}$ \\
\hline 1 & $\overline{-}$ \\
\hline
\end{tabular}

a Baged on a hydrogen plant produolng 5025 molos per scoond.

Length
Meterg
9.0
19.5
19.5
8.6
13.5
12.0
3.5
3.9
7.5
12.0
12.0
12.0
-
$=$
$=$
-
-
-

gquivalent

Fos Cost

Actual FoB

FoB Cost

Adderg

0.334
0.869

0.869
0.391

1.3886

1.3886
3.9670

$3.967^{\circ}$
$1.693^{\circ}$

0.501

0.464

0.115
0.019

1.787

1.735

0.116
0.019

1.205

0.731

20.686

0.178

$1=112$

0.002

0.009

0.018

0.034
0.047

\subsection{2}

0.002
0.017

0.068

0.094

$0.996 \quad 0.996$

$\begin{array}{r}0.996 \\ 0.169 \\ \hline\end{array}$

$\underline{0.058}$

36.313

Installed
Direot

Direot
Capital Cost

Total Plant

Investront

2.267
6.252

6.252
2.721

3.009

3.004

2.948

0.345
0.057

8.232
8.232

3.597

7.123

22.772

4.057

3.947
0.578

0.086

2.075

27.194

0.413

3.020

0.631

0.009

0.032

0.067

0.12

0.012
0.043

0.173

0.092

2.148

3.23日

0.250

$\begin{array}{r}3.238 \\ 0.329 \\ \hline\end{array}$

52.560

67.640 
Pumps are cross-connected such that one installed spare backs up the active six. The power recovery turbines are not spared except by a by-pass valve.

The column labeled "Total Plant investment Basis" is Table 7.3-1 indicates that the major unit costs of Section I are associated with the Heat Exchanger Reactor (R-101). The cost of R-101 be decreased if more of the heat load is shifted to water-based heat exchangers. If the power bottoming cycle were eliminated the cost of R-10i would be significantly decreased due to the much larger differential temperatures across the exchanger.

\subsection{2 $\mathrm{H}_{20 \mathrm{SO}_{4}}$ Processing Step (Section II))}

The simpliffed schematic for the Sulfuric Acid Processing step was presented in Figures 5.4-1. Detalled 1ists of the equipment required for - $\mathrm{H}_{2} \mathrm{SO}_{4}$ concentration and decomposition together with cost data are presented in Tables 7.3-2. All cost estinates were made ustirg Guthrle's techniques. $(5,6)$

The major costs in Section II are associated with heat transfer equipment. Silicon carbide is the materlal of chotce for heat transfer surfaces where 11quid-gas interfaces occur. sllicon carbide is used for all heat transfer involving concetrated sulfuric actd except in the Recuperator/Decomposer Preheater. Incoloy-800H is used in the Recuperator/Decomposer Preheater as only gases exist at the temperatures encountered.

Yessels are fabricated frow Fluorocarbon-lined mild steel, with this ining thermally insulated from the process via acid brich linings.

Costs of silicon carbfde and vessel liners are treated as adders to the base carbon steel equfpment costs. Stlicon carbide U-tube costs are estimated to be $\$ 32.7 / \mathrm{M}(8)$ for the $5 \mathrm{~cm}$ diameter tubes specified for the $\mathrm{H}_{2} \mathrm{SO}_{4}$ vaporizer, and this cost was used in estimating the rest of the sllicon carbon heat exchangers.

\subsubsection{HI Concentration Step (Section III)}

Capital costs for Section III are presented in Table 7.3-3. The simplified flow diagram for this section was presented in Figure 5.7-1. 
Table 7.3-2 Preliminary Capital Costa for Seotion II

\begin{tabular}{|c|c|c|c|c|c|c|c|c|}
\hline $\begin{array}{l}\text { I tera } \\
\text { No. }\end{array}$ & & $\begin{array}{l}\text { Parallel } \\
\text { Undts }\end{array}$ & $\begin{array}{l}\text { Diamster } \\
\text { Materg }\end{array}$ & $\begin{array}{l}\text { Leneth } \\
\text { Maters }\end{array}$ & $\begin{array}{l}\text { Equivalent } \\
\text { Hid Steol } \\
\text { FOB Cost }\end{array}$ & $\begin{array}{l}\text { Actus I FCD } \\
\text { Cost Plud } \\
\text { Adders }\end{array}$ & $\begin{array}{l}\text { Installed } \\
\text { Direct } \\
\text { Capital Cost }\end{array}$ & $\begin{array}{l}\text { Total Plant } \\
\text { Investment } \\
\text { Basis }\end{array}$ \\
\hline $\begin{array}{l}c 201 \\
c 202\end{array}$ & $\begin{array}{l}\text { Iaobaria Concentrator Vegsel } \\
\text { l.o* Pressure Distillation Column }\end{array}$ & $\begin{array}{l}2 \\
2\end{array}$ & $\begin{array}{l}5.0 \\
4.5\end{array}$ & $\begin{array}{l}30.0 \\
12.0\end{array}$ & $\begin{array}{l}0.625 \\
0.162\end{array}$ & $\begin{array}{l}2.134 \\
0.953\end{array}$ & $\begin{array}{l}3.634 \\
: .572\end{array}$ & $\begin{array}{l}4.658 \\
1.980\end{array}$ \\
\hline R2O1 & Decomposer Vossol & 8 & 6.0 & 12.0 & 0.900 & 15.829 & 18.659 & 22.159 \\
\hline $\begin{array}{l}\text { s201 } \\
\text { s202 } \\
\text { S203 } \\
\text { S204 } \\
\text { s205 }\end{array}$ & $\begin{array}{l}\text { Condensate Soparator on } \mathrm{C} 201 \\
\text { Condonsate Separator on c202 } \\
\text { Intermed1ate Flash Separator } \\
\text { Secondary Condensatis Separator } \\
\text { Acid Knock-Out Drim }\end{array}$ & $\begin{array}{l}2 \\
2 \\
2 \times 2 \\
2 \times 2 \\
2 \times 5\end{array}$ & $\begin{array}{l}1.4 \\
3.6 \\
1.4 \\
3.6\end{array}$ & $\begin{array}{l}2.4 \\
4.8 \\
2.4 \\
3.0\end{array}$ & $\begin{array}{l}0.035 \\
0.155 \\
0.070 \\
0.211\end{array}$ & $\begin{array}{l}0.073 \\
0.650 \\
0.146 \\
0.854\end{array}$ & $\begin{array}{l}0.156 \\
1.016 \\
0.312 \\
1.352\end{array}$ & $\begin{array}{l}0.200 \\
1.290 \\
0.416 \\
1.719\end{array}$ \\
\hline $\begin{array}{l}E 201 \\
E 202 \\
E 203 \\
E 204 \\
E 206 \\
E 207 \\
E 20 B \\
E 209 \\
E 210 \\
E 211 \\
E 212 \\
E 213 \\
E 214\end{array}$ & 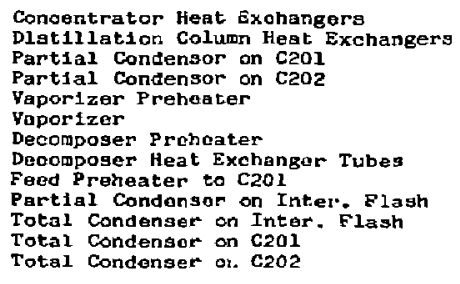 & $\begin{array}{c}-- \\
-2 \\
2 \\
2 \\
4 \\
16 \\
32 \\
-\overline{6} \\
2 \times 2 \\
2 \times 2 \\
8 \\
4\end{array}$ & $\begin{array}{l}-- \\
1.0 \\
1.2 \\
3.0 \\
3.0 \\
3.0 \\
-- \\
3.0 \\
1.2 \\
1.5 \\
2.0 \\
2.0\end{array}$ & $\begin{array}{r}7 .- \\
6.0 \\
6.0 \\
7.2 \\
10.0 \\
9.0 \\
7.0 \\
7.2 \\
6.0 \\
6.0 \\
6.0\end{array}$ & $\begin{array}{l}1.394 \\
0.745 \\
0.103 \\
0.116 \\
0.478 \\
2.361 \\
2.62 . \\
2.683 \\
0.732 \\
0.238 \\
0.293 \\
0.857 \\
0.457\end{array}$ & $\begin{array}{r}5.808 \\
1.804 \\
0.103 \\
0.116 \\
1.955 \\
10.670 \\
25.969 \\
16.095 \\
3.995 \\
0.238 \\
0.293 \\
0.857 \\
0.457\end{array}$ & $\begin{array}{r}9.449 \\
3.750 \\
0.236 \\
0.264 \\
3.173 \\
16.736 \\
39.696 \\
25.480 \\
3.995 \\
0.543 \\
0.569 \\
1.794 \\
1.043\end{array}$ & $\begin{array}{r}11.995 \\
4.916 \\
0.351 \\
0.398 \\
4.034 \\
21.147 \\
47.298 \\
31.475 \\
7.348 \\
0.017 \\
1.006 \\
2.757 \\
1.569\end{array}$ \\
\hline $\begin{array}{l}\text { P201 } \\
\text { P202 } \\
\text { P203 }\end{array}$ & $\begin{array}{l}\text { Dilute hald Feed Pump } \\
\text { Vaporizer Foed Pump } \\
\text { Dlstillation Column Ovorhead Pump }\end{array}$ & $\begin{array}{l}6+1 \\
6+1 \\
6+1\end{array}$ & $\begin{array}{l}-- \\
\overline{-}\end{array}$ & $\begin{array}{l}\overline{-} \\
\overline{-}\end{array}$ & $\begin{array}{l}0.434 \\
0.145 \\
0.027\end{array}$ & $\begin{array}{l}1.306 \\
0.435 \\
0.027\end{array}$ & $\begin{array}{l}2.415 \\
0.805 \\
0.063\end{array}$ & $\begin{array}{l}3.140 \\
1.047 \\
0.096\end{array}$ \\
\hline $\begin{array}{l}\text { TE201 } \\
\text { TE20? }\end{array}$ & $\begin{array}{l}\text { Liquid Expander Fram t.P. Cono. } \\
\text { Liquid Expander Fram Inter, Flash }\end{array}$ & $\begin{array}{l}1 \\
1\end{array}$ & $=$ & -- & $\begin{array}{l}0.180 \\
0.053\end{array}$ & $\begin{array}{l}\text { C.180 } \\
0.053\end{array}$ & $\begin{array}{l}0.427 \\
0.125\end{array}$ & $\begin{array}{l}0.642 \\
0.189 \\
\end{array}$ \\
\hline Tatgl & Cap1tal Cost & & & & 16.066 & 91.050 & 137.364 & 172.655 \\
\hline
\end{tabular}

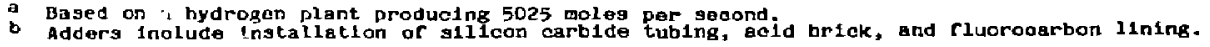


Table 7.3-3 Preliminary Capttal Costs for Section III ${ }^{\mathrm{a}}$ - MS. July 1980

\begin{tabular}{|c|c|c|c|c|c|c|c|c|}
\hline $\begin{array}{l}\text { Iter } \\
\text { No. }\end{array}$ & & $\begin{array}{l}\text { Parallel } \\
\text { Units }\end{array}$ & $\begin{array}{l}\text { Dianeter } \\
\text { Meters }\end{array}$ & $\begin{array}{l}\text { Length } \\
\text { Meters }\end{array}$ & $\begin{array}{l}\text { Equivalent } \\
\text { Mild Steel } \\
\text { FoB Cost }\end{array}$ & $\begin{array}{l}\text { Actual FoB } \\
\text { Cost Plus } \\
\text { Adders } \\
\end{array}$ & $\begin{array}{c}\text { Installed } \\
\text { ofrect } \\
\text { Capital cost } \\
\end{array}$ & $\begin{array}{l}\text { Total P1 ant } \\
\text { Investment } \\
\text { gassis }\end{array}$ \\
\hline $\begin{array}{l}\mathrm{C} 301 \\
\mathrm{C} 302 \\
\mathrm{C} 303\end{array}$ & $\begin{array}{l}\text { Jodine wash col umn } \\
\text { lod kne knockout column } \\
\text { HI distillation }\end{array}$ & $\begin{array}{r}3 \\
10 \\
3\end{array}$ & $\begin{array}{l}4.5 \\
7.7 \\
6.9\end{array}$ & $\begin{array}{l}19.0 \\
24.0 \\
21.6\end{array}$ & $\begin{array}{l}0.343 \\
3.137 \\
0.912\end{array}$ & $\begin{array}{l}2.769^{b c c} \\
29.265^{b c} \\
22.194^{b}\end{array}$ & $\begin{array}{r}3.346 \\
34.476 \\
25.016\end{array}$ & $\begin{array}{r}4.139 \\
42.272 \\
29.478\end{array}$ \\
\hline $\begin{array}{l}5301 \\
5303 \\
5304 \\
5305 \\
5306\end{array}$ & 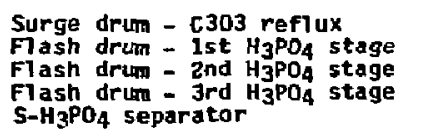 & $\begin{array}{l}3 \\
6 \\
5 \\
4 \\
3\end{array}$ & $\begin{array}{l}2.7 \\
6.0 \\
3.6 \\
6.6 \\
5.9\end{array}$ & $\begin{array}{l}10.2 \\
9.0 \\
16.2 \\
10.7 \\
22.2\end{array}$ & $\begin{array}{l}0.128 \\
0.499 \\
0.357 \\
0.463 \\
0.558\end{array}$ & $\begin{array}{l}0.424 \mathrm{~b} \\
1.660^{\mathrm{c}} \\
1.192^{\mathrm{c}} \\
3.237 \\
3.907\end{array}$ & $\begin{array}{l}0.756 \\
2.949 \\
2.114 \\
5.797 \\
6.789\end{array}$ & $\begin{array}{l}0.969 \\
3.780 \\
2.708 \\
7.027 \\
8.242\end{array}$ \\
\hline $\begin{array}{l}E 302 \\
\text { E303 } \\
\text { E304 } \\
\text { E305 } \\
\text { E306 } \\
E 307 \\
\text { E308 } \\
\text { E309 } \\
\text { E310 } \\
\text { E311 } \\
\text { E312 }\end{array}$ & 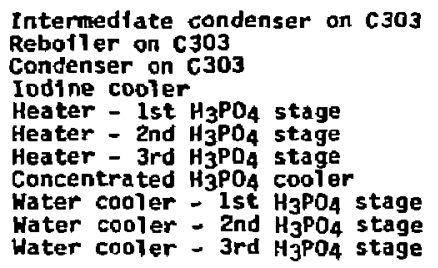 & $\begin{array}{r}3 \\
6 \\
6 \\
1 \\
65 \\
50 \\
49 \\
6 \\
1 \\
1 \\
1\end{array}$ & $\begin{array}{l}1.6 \\
1.1 \\
1.6 \\
1.4 \\
1.5 \\
1.5 \\
1.5 \\
1.8 \\
1.7 \\
1.8 \\
1.7\end{array}$ & $\begin{array}{l}12.0 \\
12.0 \\
12.0 \\
12.0 \\
12.0 \\
12.0 \\
12.0 \\
12.0 \\
12.0 \\
12.0 \\
12.0\end{array}$ & $\begin{array}{l}0.148 \\
0.903 \\
0.820 \\
0.102 \\
3.229 \\
2.639 \\
1.779 \\
2.148 \\
0.239 \\
0.224 \\
0.160\end{array}$ & $\begin{array}{l}1.496 \\
3.9951 \\
4.063 \\
1.023 \\
25.696 \\
21.417 \\
13.083 \\
21.701 \\
1.745 \\
7.647 \\
1.181\end{array}$ & $\begin{array}{r}2.081 \\
5.110 \\
5.480 \\
1.423 \\
34.975 \\
29.262 \\
17.720 \\
30.168 \\
2.386 \\
2.229 \\
1.600\end{array}$ & $\begin{array}{r}2.513 \\
6.608 \\
6.967 \\
1.719 \\
42.920 \\
35.789 \\
21.812 \\
36.434 \\
2.938 \\
2.643 \\
1.970\end{array}$ \\
\hline $\begin{array}{l}\text { P301 } \\
\mathbf{P 3 0 2} \\
\mathbf{p 3 0 4} \\
\text { P305 }\end{array}$ & $\begin{array}{l}\text { Lower phase feed pump } \\
\text { Iodine wash water purrop } \\
\text { Feed pump - C } 303 \\
\text { Concentrated } \mathrm{H}_{3} \mathrm{~F} \text { : }\end{array}$ & $\begin{array}{l}10+1 \\
3+1 \\
10+1 \\
10+1\end{array}$ & $\begin{array}{l}\bar{z} \\
\bar{z}\end{array}$ & $\begin{array}{l}\bar{z} \\
\bar{z}\end{array}$ & $\begin{array}{l}0.212 \\
0.006 \\
0.742 \\
0.478\end{array}$ & $\begin{array}{l}0.425 \\
0.006 \\
1.486 \\
0.956\end{array}$ & $\begin{array}{l}0.814 \\
0.013 \\
2.721 \\
1.750\end{array}$ & $\begin{array}{l}1.112 \\
0.021 \\
3.749 \\
2.406\end{array}$ \\
\hline $\begin{array}{l}\text { TE302 } \\
\text { TE3003 } \\
\text { TEE304 } \\
\text { TE305 }\end{array}$ & $\begin{array}{l}\text { 1st } \mathrm{H}_{3} \mathrm{PO}_{4} \text { stage } \mathrm{PR} \text { turbine } \\
\text { 2nd } \mathrm{H}_{3}^{\mathrm{PPO}} \text { stage } \mathrm{PR} \text { turbine } \\
3 \text { sd } \mathrm{HH}_{3} \mathrm{PO}_{4} \text { stage PR turbine } \\
\text { Ioddne power recovery turbine }\end{array}$ & $\begin{array}{l}1 \\
1 \\
1 \\
1\end{array}$ & $\bar{\Sigma}$ & $\bar{E}-$ & $\begin{array}{l}0.398 \\
0.257 \\
0.240 \\
0.087\end{array}$ & $\begin{array}{l}0.398 \\
0.257 \\
0.240 \\
0.171\end{array}$ & $\begin{array}{l}0.741 \\
0.562 \\
0.516 \\
0.291\end{array}$ & $\begin{array}{l}1.092 \\
0.892 \\
0.757 \\
0.396\end{array}$ \\
\hline $\begin{array}{l}\mathrm{TC} 301 \\
\mathrm{TC} 302 \\
\mathrm{TC} 303\end{array}$ & $\begin{array}{l}\text { 1st } \mathrm{H}_{3} \mathrm{PO}_{4} \text { stage steam comp. } \\
\text { 2nd } \mathrm{H}_{3} \mathrm{PO}_{4} \text { stage steam comp. } \\
\text { 3rd } \mathrm{H}_{3} \mathrm{PO}_{4} \text { stage steam comp. }\end{array}$ & $\begin{array}{l}6 \\
5 \\
4\end{array}$ & $\overline{-}$ & $\overline{-}$ & $\begin{array}{l}17.321 \\
14.434 \\
11.547 \\
\end{array}$ & $\begin{array}{r}17.321 \\
19.562 \\
11.547 \\
\end{array}$ & $\begin{array}{r}37.378 \\
31.149 \\
24.919 \\
\end{array}$ & $\begin{array}{l}61.467 \\
46.949 \\
37.559 \\
\end{array}$ \\
\hline Total & Cap1tal Cost & & & & 64.610 & 214.038 & 314.531 & 417.328 \\
\hline
\end{tabular}

a Based on a hydrogen plant producing 5025 moles per second.

b Adder includes field instailation of packing 
Materials of construction and s sting techniques are similar to those of Section 1. Where, because of thermal or mechantcal ifmitations, fiuorocarbon linings are not acceptable, we have used Hastelloy-C.

The hydrogen iodide concentration step is the most capital intensive portion of the chemical plant. Although significant costs are assoctated with fodine knockout and hydrogen iodide disttilation, the largest costs are associated with phosphoric acid concentration.

The high cost components of the phosphoric acid concentration system are steam compressors and heat exchangers. The compressor costs are based on vendor estimates $(9)$ and reduced to the 1980 base using the Mas(7) cost index. These compressor costs appear to be fixed unless future developments bring down the relative cost of turbine compressors. Flowsheet modifications have the potential for reducing the heat transfer costs, particularly if direct contact heat transfer is employed between inmiscible streans in Sections I and III and between Sections III and IV. The large amount of rotating machinery in the phosphoric acid concentration system makes this part of the process a potential source of downtime. The compressors in the third evaporation stage were deliberately oversized to make them identical to the first and second stage units. If any one of the 15 units is down, intermediate pressures may be shifted to permit operation at $93 \%$ of capacity with only a slight overall efficlericy loss.

\subsubsection{HI Decomposition Step (Section IV)}

The HI decomposition step has the lowest flow rates and lowest costs of the four chemical process steps. The costs are as high as given in Table 7.3-4 only because of the high pressures involved. The simplified flowsheet for Section IV was given in Figure 5.8-1.

\subsection{Chemical Plant Operating Costs}

Preliminary estimates of the operating and maintenance costs of chemical plants may be calculated from the F.0.B. costs of the capital equipment. According to Guthrie, $(6)$ the yearly operating and maintenance cost is $20 \%$ of the direct capital cost, assuming mild steel construction. 


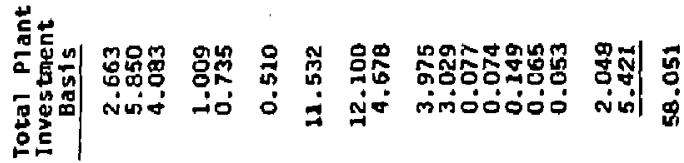

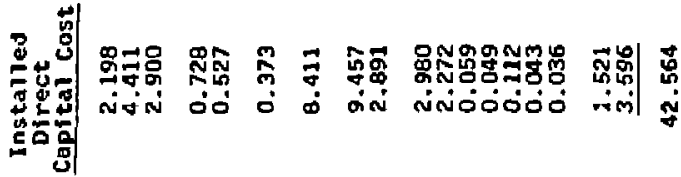

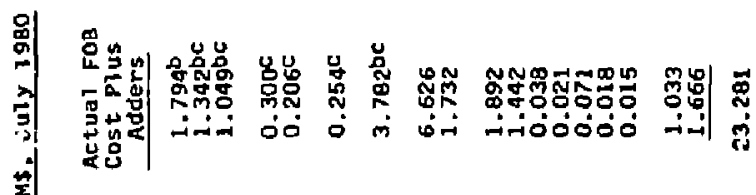

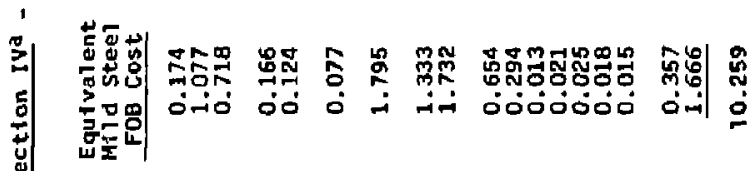

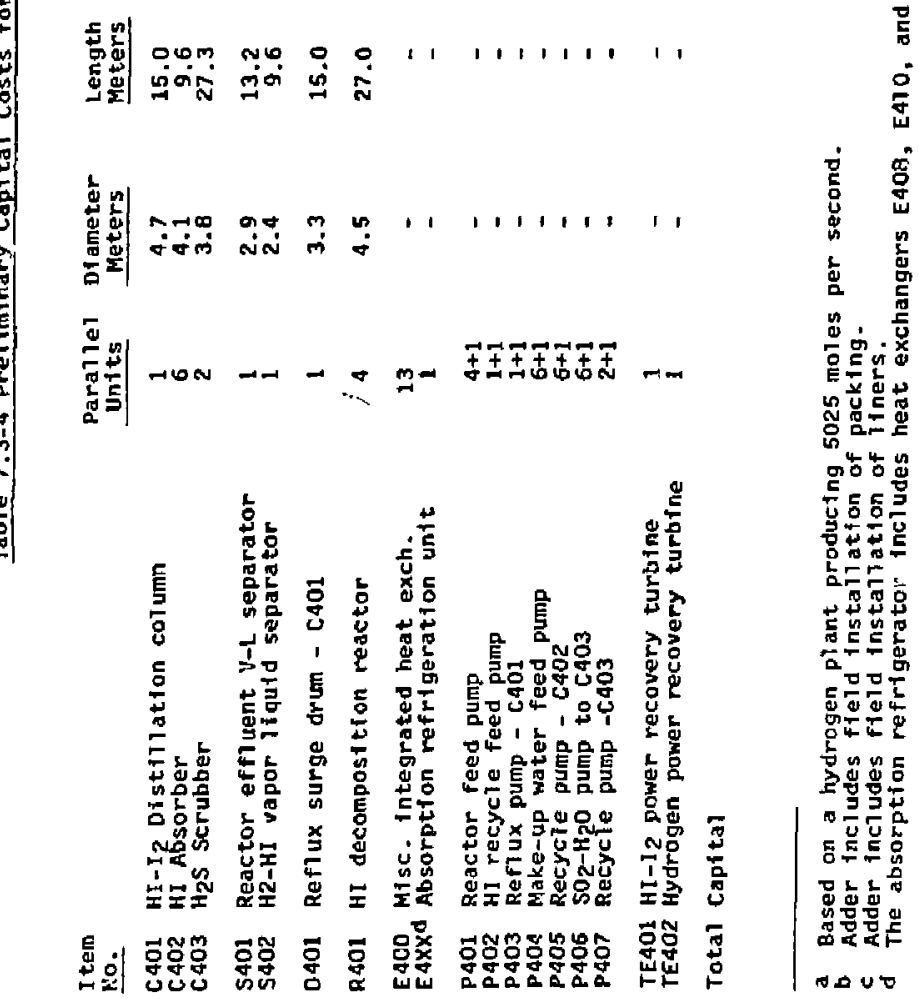


Assuming the cost of the mild steel plant is $243.2 \%$ of the F.O.B. cost of the equivalent mild steel equipment, ${ }^{(5)}$ the yeariy operating cost of the chemical plant is $\$ 48.6 \mathrm{M}$ as indicated in Table 7.4-1.

TABLE 7.4-1

Estimated Operating Costs of Chemical Plant $=$ M\$ July 1980

$\begin{array}{cccc}\text { Section } & \begin{array}{c}\text { Equivalent } \\ \text { Mild Steel } \\ \text { F.0.B. Cost }\end{array} & \begin{array}{c}\text { Total Planta } \\ \text { Investment Based } \\ \text { on Mild Steela }\end{array} & \begin{array}{c}\text { Yearly } \\ \text { Operating } \\ \text { Costb }\end{array} \\ \text { I } & 7.123 & 17.679 & 3.536 \\ \text { II } & 16.066 & 39.727 & 7.945 \\ \text { III } & 64.610 & 160.362 & 32.072 \\ \text { IV } & \underline{10.259} & \underline{25.463} & \underline{5.093} \\ & 98.058 & 243.237 & 48.646\end{array}$

\footnotetext{
a 248.2\% of F.0.B. equipment cost.

b 20\% of Total Plant Investment.
} 
1. M. S. Peters and K. D: Timmerhaus, "Plant Design and Economics for Chemical Engineers," McGraw-Hf11, New York, 1980.

4. R. H. Herner, et al, "Conceptual Design Study FY 1981, Synfueis from Fusion-Using the Tandem Mirror Reactor and a Thermochemical cycle to Produce Hydrogen." Laurence Livermore National Laboratory Report UCID-193IT.

5. K. M. Guthrie, "Capital Cost Estimating," Chemical Engineering 76, (6), 114-142 (1969).

6. K. M. Guthrle, "Capital and Operating costs for 54 Chemical Processes," Chemical Engineering 77, (13), 140-156 (1970).

7. Marshall and Swift, Los Ange7es, Equipment Cost Index, compiled quarterly, for 47 different industrles reported regularly in Chemtcal Engineering, McGraw Hil1, New York.

8. J. Smelko, Union Carbide Company, Cleveland, OH, private communication to T. Galloway of LLNL, June, 1981.

9. D. Stanwich, Ingersol Rand Company, Philipsburg, MA, private communication, August, 1982. 